IZA DP No. 5635

Short-Time Work Benefits Revisited:

Some Lessons from the Great Recession

Tito Boeri

Herbert Bruecker

April 2011 


\title{
Short-Time Work Benefits Revisited: Some Lessons from the Great Recession
}

\author{
Tito Boeri \\ IGIER, fRB, Università Bocconi, \\ CEPR and IZA \\ Herbert Bruecker \\ Institute for Employment Research (IAB), \\ University of Bamberg and IZA
}

Discussion Paper No. 5635

April 2011

IZA

P.O. Box 7240

53072 Bonn

Germany

Phone: +49-228-3894-0

Fax: +49-228-3894-180

E-mail: iza@iza.org

\begin{abstract}
Any opinions expressed here are those of the author(s) and not those of IZA. Research published in this series may include views on policy, but the institute itself takes no institutional policy positions.

The Institute for the Study of Labor (IZA) in Bonn is a local and virtual international research center and a place of communication between science, politics and business. IZA is an independent nonprofit organization supported by Deutsche Post Foundation. The center is associated with the University of Bonn and offers a stimulating research environment through its international network, workshops and conferences, data service, project support, research visits and doctoral program. IZA engages in (i) original and internationally competitive research in all fields of labor economics, (ii) development of policy concepts, and (iii) dissemination of research results and concepts to the interested public.
\end{abstract}

IZA Discussion Papers often represent preliminary work and are circulated to encourage discussion. Citation of such a paper should account for its provisional character. A revised version may be available directly from the author. 


\section{ABSTRACT \\ Short-Time Work Benefits Revisited: Some Lessons from the Great Recession*}

The Great Recession triggered a resurgence of short-time work (STW) throughout the OECD. Several countries introduced from scratch STW or significantly expanded the scope of the programmes already in place. In some countries like Italy, Japan and Germany between 2.5 and 5 per cent of the workforce participated in short-time work schemes at the trough of the recession. In this paper we analyse the rationale for short time work benefits and their effects on labour adjustment from both a cross-country and a time-series perspective. We find that STW actually contributed to reduce job losses during the Great Recession. However, the number of jobs saved, according to our macroeconomic estimates, is smaller than the full-time equivalents jobs involved by these programmes, pointing in some cases to sizeable deadweight costs. Other institutions, like plant-level bargaining over hours, wages and employment levels may be more effective than STW in encouraging adjustment along the intensive margins in presence of temporary shocks. Our results also suggest that STW cannot be readily extended to countries having much different institutional configurations as the demand for STW is very much affected by other institutions such as employment protection legislation and the degree of centralization of collective bargaining. The micro evidence from firm-level data in Germany is more encouraging as to the effectiveness of STW, pointing to rather moderate deadweight losses. We interpret this result as due to specific design features of the German STW that could make it more effective in addressing the moral hazard problems related to reliance on subsidised hour reductions. The German Kurzarbeit scheme is indeed discouraging 100 per cent hours reductions and is experience-rated.

JEL Classification: J63, J65

Keywords: intensive margin, short-time

Corresponding author:

Tito Boeri

Department of Economics

Università Bocconi

via Roentgen 1

20136 Milano

Italy

E-mail: tito.boeri@unibocconi.it

\footnotetext{
* The authors wish to thank Tullio Jappelli, Michele Pellizzari and three anonymous referees for comments on an initial draft as well as Sebastian Baehr, Andrea Catania and Andreas Hauptmann for excellent research assistance.
} 


\section{Introduction}

Germany's jobs miracle hasn't received much attention in this country - but it's real, it's striking (...) Germany came into the Great Recession with strong employment protection legislation. This has been supplemented with a "short-time work scheme", which provides subsidies to employers who reduce workers' hours rather than laying them off. These measures didn't prevent a nasty recession, but Germany got through the recession with remarkably few job losses.

(Paul Krugman, NYT, 12 November 2009)

The above quotes from the 2008 Nobel Laureate Paul Krugman, one of the most influential opinion-makers in the US, offer a good example of the rediscovery of short-time work (STW) schemes during the Great Recession. In the previous two decades all the attention of policymakers, "social partners" and scholars of labour economics had been turned away from this institution. It suddenly became very popular in 2009. Kurzarbeit, the German version of STW, is being celebrated in policy discussions around the world as the main factor behind the German "job miracle". In order to find so much support for a European labour market institution in the US one has to go back to the 1960s when senior US policy-makers like Robert Myers were stating that "it would be short-sighted to ignore Europe's recent success in holding down unemployment" declaring to be "looking enviously at our European friends to see how they do it". The adoption of STW for countries where this instrument currently does not exist or plays only a minor role has also been advocated, inter alia, in the Spring edition of the 2010 IMF World Economic Outlook and in the 2010 issue of the OECD Employment Outlook.

Is all this praise justified? Is the German employment miracle really associated with STW? Why then did short-time work not play the same role during the previous recessions and in other countries that also have a long tradition with STW schemes? And can STW be adopted also in completely different institutional landscapes, e.g., in the US labour market? These issues are relevant in a context where it is proving very difficult in most advanced countries to absorb the 30 million unemployed persons who lost their jobs during the Great Recession.

There are a number of trade-offs involved by the introduction of a STW scheme: this institution may distort adjustment along the intensive margin of hours of work; it may prevent reallocation of workers from firms facing structural problems to firms with a strong growth potential, thereby reducing the "cleansing effects" of recessions. STW schemes are also costly measures although much less than bank rescue operations. Expenditure on STW climbed in 2009 to some 5 billion Euros in Germany, 5.5 billion Euros in Italy and roughly 6 billion Euros in Japan, between .1 and .3 per cent of GDP in these three countries which made the largest use of this scheme.

The aggregate figures are, prima facie, rather impressive. In Germany, Japan and Italy, the number of employees involved in STW attained at the trough of the recession between 2.5 
and 5 per cent of the labour force. At the same time, unemployment had increased in these countries, heavily affected by export demand shocks and the subsequent decline in output, only moderately if at all. This does not imply that the initial success in containing unemployment is related to STW. Other institutions, such as employment protection legislation (EPL) or decentralized bargaining allowing to reduction in working hours to preserve jobs, may have been equally, if not more, important in avoiding large scale layoffs. Moreover, STW can be at best a device to buy time when facing a temporary shock, just like notice periods in EPL. Over a few quarters, if macroeconomic conditions do not improve, STW may well turn out to be much less effective in containing job losses. STW is also a multidimensional institution that has to be properly designed in terms of the replacement rates offered for the income-hours reductions, the minimum and maximum duration of benefits, the eligibility conditions, the work-tests required to beneficiaries, etc. Different countries have made different choices as to these design features of STW and we can learn much by comparing the performance of different arrangements in the context of the Great Recession.

Surprisingly enough, there is little theoretical work on the rationale for STW and, above all, on those design features of STW which are bound to improve its performance in containing wage deflation and reducing excessive layoffs. There are also a very few empirical studies on the macroeconomic effects of STW and on the relationship between short-time work benefits and job reallocation at the industry and firm levels.

The purpose of this paper is to contribute to filling these gaps by exploiting the policy experiments with STW carried out during the Great Recession in adjusting the size and the coverage of this instrument as well as its duration and financing. In particular, our aim is to contribute to a better understanding of the key features that make short-time work benefits effective in containing job losses and preventing wage deflation without obstructing job reallocation in the aftermath of a recession.

We find that STW actually contributed to reduce job losses during the Great Recession. However, the number of jobs saved, according to our macroeconomic estimates, is smaller than the full-time equivalents involved by these programmes, pointing in some cases to sizeable deadweight costs. Other institutions, like plant-level bargaining over hours, wages and employment levels may be more effective in encouraging adjustment along the intensive margins in presence of temporary shocks. Our results also suggest that STW cannot be readily extended across countries having much different institutional configurations as the demand for STW is very much affected by other institutions such as employment protection legislation and the centralization of wage bargaining. We also identify design features of STW that could make it more effective in addressing the moral hazard problems related to reliance on this policy instrument. The German Kurzarbeit scheme is particularly well designed as it discourages 100 per cent hours reductions and is experience-rated. This contributes to explain why our microeconomic estimates find little evidence of deadweight costs in Germany.

The paper is structured in four parts: First, in Section 2, we present some stylized facts about the adjustment along intensive and extensive margins and the scope of short-time work schemes in G7 countries. We also describe how these schemes operate in practice in the countries that make the largest use of it. Next, in Section 3 we review the theory of STW and 
discuss the relevant interactions of short-time work with other institutions, such as employment protection legislation and unemployment benefits. Section 4 is devoted to empirically assess take-up rates and to investigate the contribution offered by STW to containing job losses during the Great Recession in the different countries. Finally, Section 5 highlights the design features of STW which contribute to improve the effectiveness of these institutions in preventing excess job losses during the recession without hindering structural change and the reallocation of jobs and workers in the recovery.

\section{The Resurgence of Short-Time Work}

Krugman, in his op-ed probably had in mind some variant of Figure 1 . The top panel displays the adjustment of the extensive and intensive margins during the Great Recession, where the extensive margin is defined as the employment rate, that is number of employed people over the working age population, and the intensive as the hours worked per employee. In spite of the greater severity of the recession in Germany (where output fell by a cumulative 6.6 per cent) than in the US (-4.1 per cent), the employment rate in Germany did not decline (and unemployment did not rise) while very large job losses were experienced in the US, where employment felt by a cumulative 6 per cent and unemployment more than doubled attaining two-digits levels.

Figure 1
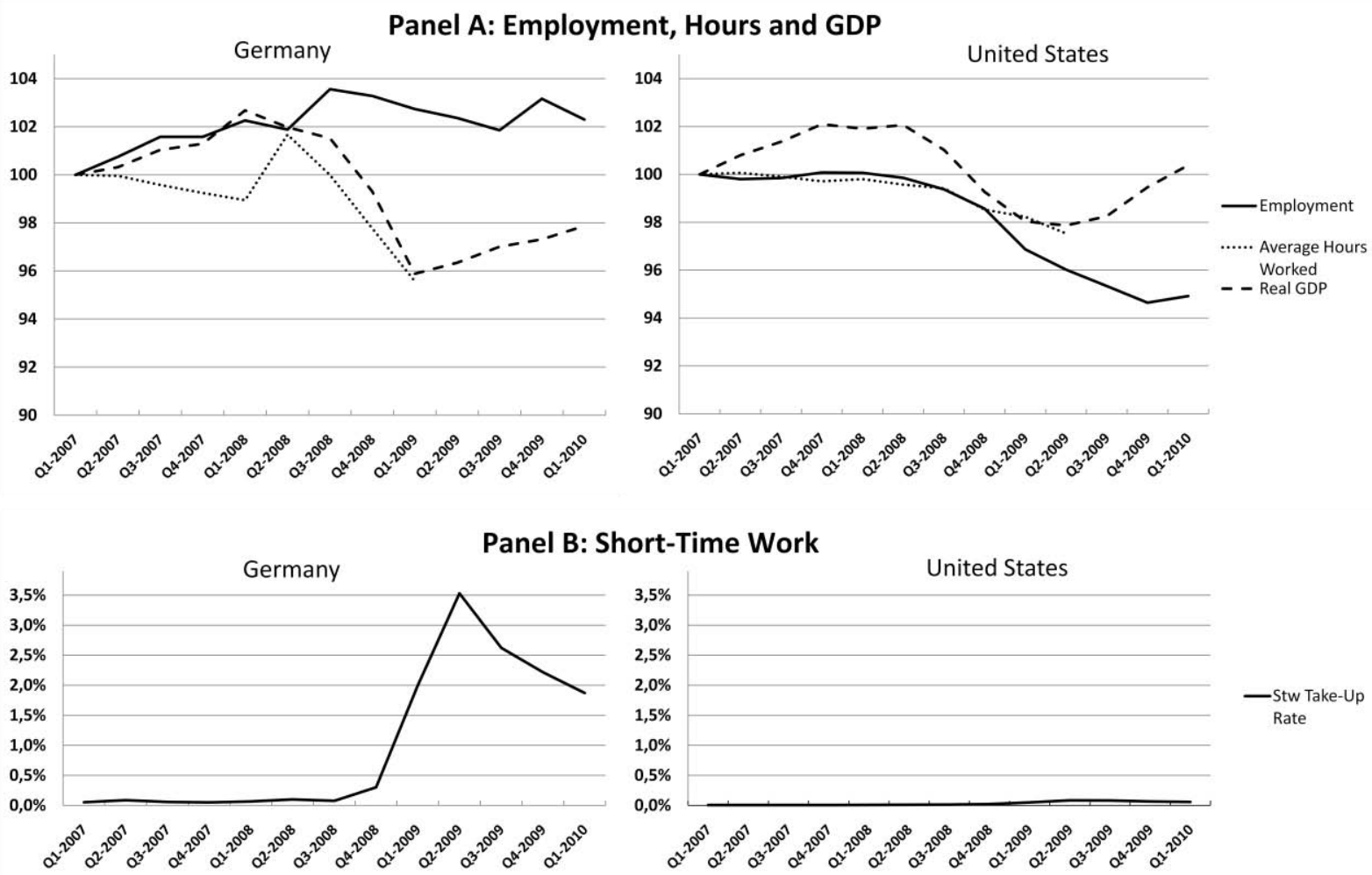

Notes: 2007 Q1=100 for employment, average hours worked and real GDP. STW take-up rate is computed as \% of all employees.

Source: average hours worked and real GDP from IMF; employment from OECD; STW for Germany from Alexander Hijzen and Danielle Venn (2010), STW for US from US Labour Department. 
The bottom panel of Figure 1 shows the fraction of the labour force involved in Short-time Work in the two countries. While Germany made a very large use of its Kurzarbeit scheme aimed at preserving jobs in firms experiencing temporary falls in demand, in the US there was not a significant pick-up in the work sharing arrangements existing in a number of States, in spite of the gravity of the recession. The parallel between the asymmetries in the adjustment along the two margins and the scale of the STW is quite striking. Hence, the praise of the STW by the 2008 Nobel laureate.

Germany, however, is not the only country to have enhanced STW during the recession. A similar strategy was followed also by Japan and Italy that experienced output falls comparable to those of Germany (-6.8 per cent in Italy and -8.7 per cent in Japan). As shown by Figure 2 , in the latter two countries adjustment occurred to a large extent along the extensive margin in spite of a sizeable expansion of short-time work schemes.

Figure 2
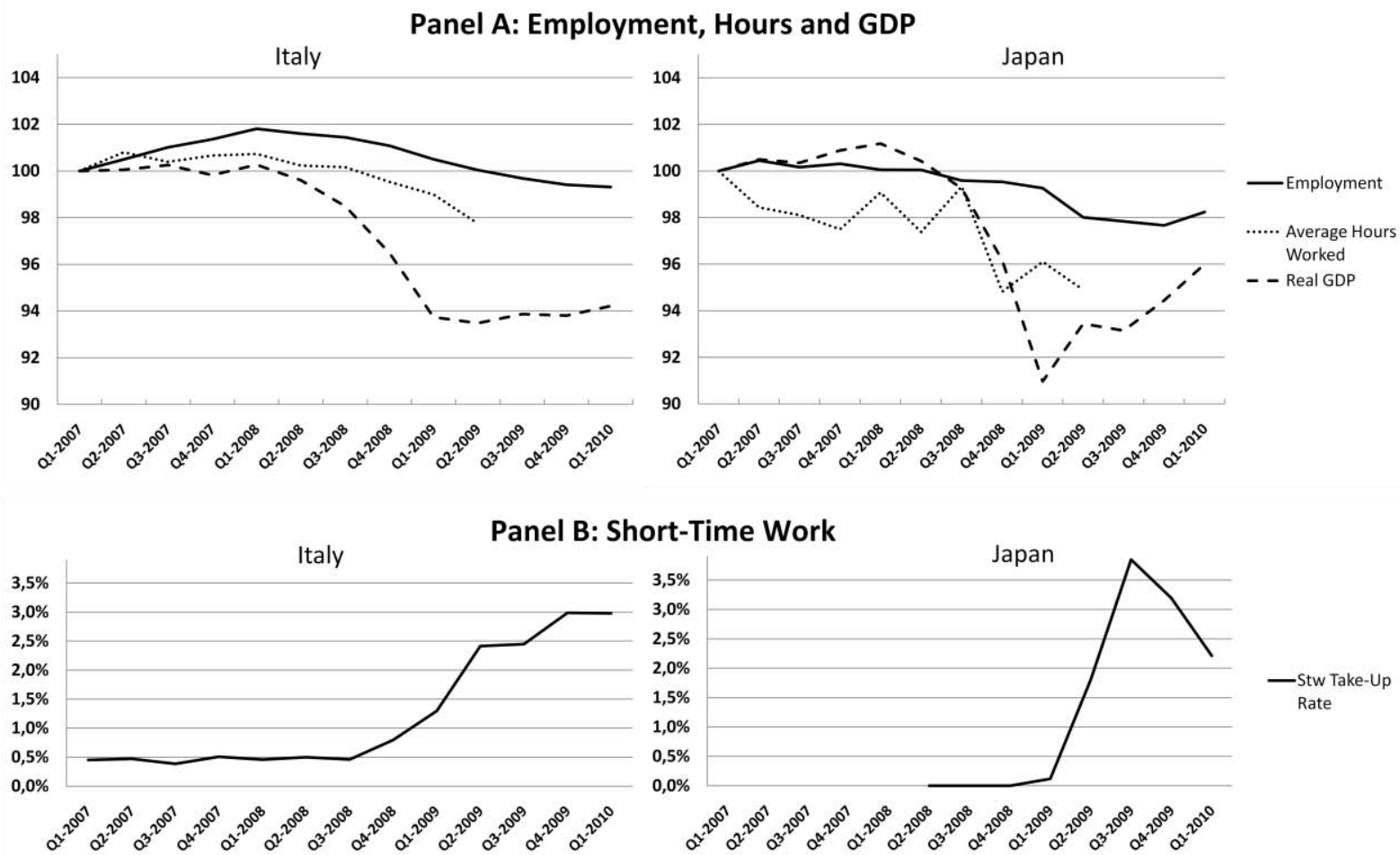

Notes: Q1=100 for employment, average hours worked and real GDP. STW take-up rate is computed as \% of the labour force.

Source: average hours worked and real GDP from IMF; employment from OECD and STW from Alexander Hijzen and Danielle Venn (2010).

Another observation pointing to the role of STW concerns the role played by adjustment along the intensive margins compared with previous recession episodes. Table 1 looks at the share of total hours decline during downturns (identified by using the OECD classification of recessions) in the component related to hours per employee variation and the component related to changes in the number of employees. In particular, we apply the following decomposition of the variance in total hours

$$
\log (\Delta \mathrm{H})=\Delta \log (\mathrm{h})+\Delta \log (\mathrm{n})
$$


where $\Delta H$ denotes the first difference in total hours worked, while $h$ and $n$ refer to the average number of hours worked per employee and the total number of employees respectively. The first term on the right-hand-side represents the variation along the intensive margin and the second term the variation along the extensive margin. They are both expressed in Table 1 as a fraction of the total hours variation. Our data cover the period 1970 to 2009, hence historical recessions include the two oil shocks of the 1970s, the 1992 recession, the dotcom bust as well as country-specific recessions.

\section{Table 1 The contribution of the intensive margin to labour adjustment}

\begin{tabular}{lrc}
\hline & $2008-2009$ & $\begin{array}{c}\text { Historical Average } \\
\text { (previous recessions) }\end{array}$ \\
\hline Canada & $56.32 \%$ & $41 \%$ \\
France & $55.13 \%$ & $58 \%$ \\
Germany & $117.35 \%$ & $48 \%$ \\
Italy & $79.47 \%$ & $31 \%$ \\
Japan & $91.31 \%$ & $89 \%$ \\
UK & $48.34 \%$ & $46 \%$ \\
US & $35.64 \%$ & $47 \%$ \\
\hline
\end{tabular}

Notes: adjustment in intensive margin is equal to the rate of change of average hours worked per worker from peak to trough divided by the rate of change of total hours worked over the same period.

Source: number of employees from OECD; average hours worked from IMF

The table indicates that Germany and Italy, the two countries of the G7 with the largest use of work-sharing arrangements displayed in 2008-9 more adjustment along the intensive margin than the other $\mathrm{G} 7$ countries and they did so more than in previous recessions. Japan also relied more than other countries on hours adjustment but not more than in previous recessions. Also in Canada the importance of the intensive margin as shock absorber was enhanced in the Great Recession, while the opposite happened in the US, where firms adjusted to the recession mainly by dismissing workers rather than by reducing working hours.

Short-time work is likely to have played an important role in promoting more adjustment of hours than headcounts employment. Table 2 provides some information on the scale of STW in the countries for which this information is available and meaningful cross-country comparisons can be carried out. In particular, we provide three measures of the size of these programmes. The first measure is the raw number of participants as a percentage of all employees. Some short-time workers may reduce hours of work by a very small amount and yet they would be counted by this measure just like workers involved in a 100 per cent hours reduction. The second measure involves some adjustment for the actual hours reductions: it is based on an estimate of the number of full-time equivalent jobs involved by these schemes, normalized by the population of full-time employees. The estimate of the full-time equivalents draws on information collected by Hijzen and Venn (2010) on the average hours reduction in different STW schemes. Finally, the third measure takes hours of STW over total hours worked in the previous five years (a proxy for standard hours at the aggregate level). 
Clearly different measures address different issues (how many jobs involved? how sizeable is the hours reduction?) and therefore it is useful to look at them in conjunction. We also show the levels of these measures before the Great Recession and in 2009.

Table 2 The scale of STW programmes

\begin{tabular}{|c|c|c|c|c|c|c|}
\hline \multicolumn{7}{|c|}{ Average quarterly take-up rates by country } \\
\hline \multirow[t]{2}{*}{ Country } & \multicolumn{2}{|c|}{$\begin{array}{c}\text { Stock of Participants } \\
\text { over Total } \\
\text { (dependent) } \\
\text { Employment }\end{array}$} & \multicolumn{2}{|c|}{$\begin{array}{c}\text { FTE over Full-Time } \\
\text { Employees }\end{array}$} & \multicolumn{2}{|c|}{$\begin{array}{l}\text { STW Hours over Total } \\
\text { Hours Worked }\end{array}$} \\
\hline & 2007 & 2009 & 2007 & 2009 & 2007 & 2009 \\
\hline Austria & $0.0 \%$ & $0.7 \%$ & $0.0 \%$ & $0.2 \%$ & $0.0 \%$ & $0.2 \%$ \\
\hline Belgium & $3.2 \%$ & $5.6 \%$ & $1.8 \%$ & $3.0 \%$ & $1.4 \%$ & $2.4 \%$ \\
\hline Canada & $0.0 \%$ & $0.3 \%$ & $0.0 \%$ & $0.1 \%$ & $0.0 \%$ & $0.1 \%$ \\
\hline Finland & $0.4 \%$ & $1.7 \%$ & $0.4 \%$ & $2.0 \%$ & $0.4 \%$ & $1.5 \%$ \\
\hline France & $0.4 \%$ & $0.9 \%$ & $0.1 \%$ & $0.2 \%$ & $0.1 \%$ & $0.2 \%$ \\
\hline Germany & $0.1 \%$ & $3.2 \%$ & $0.2 \%$ & $1.8 \%$ & $0.0 \%$ & $1.1 \%$ \\
\hline Italy & $0.7 \%$ & $3.3 \%$ & $0.7 \%$ & $3.2 \%$ & $0.4 \%$ & $2.0 \%$ \\
\hline Japan* & $0.0 \%$ & $2.7 \%$ & $0.0 \%$ & $1.1 \%$ & $0.0 \%$ & $0.7 \%$ \\
\hline Norway & $0.1 \%$ & $0.6 \%$ & $0.1 \%$ & $0.2 \%$ & $0.1 \%$ & $0.7 \%$ \\
\hline Switzerland & $0.0 \%$ & $1.1 \%$ & $0.0 \%$ & $0.5 \%$ & $0.0 \%$ & $0.4 \%$ \\
\hline
\end{tabular}

Notes: Japan 2007 refers to 2008 Q2.

FTE take-up rate $=($ Stock of Participants into STW $\times$ Average Hours Reduction $) /($ Full-time Employees + STW fulltime equivalents)

STW Hours over Total Hours calculated as follows: Total STW Hours/(Previous five years average of total hours worked in the economy + Total STW hours), where Total STW Hours = (STW full-time equivalents $x$ average number of hours worked by a full-time worker in a year).

Source: data on short-time workers drawn from Alexander Hijzen and Danielle Venn, 2010 OECD Working Paper; data on total hours worked and total labour force from OECD.

As shown in the Table, in many countries these schemes were rather insignificant in 2007, while they had climbed to relatively high levels by 2009. In addition to Germany, Japan and Italy, also Belgium and Finland enrolled in these schemes more than 1 per cent of the labour force and up to 2 per cent of the total hours worked under normal business conditions.

There are a number of issues that are raised by these observations. It is important addressing them in order to prevent that the resurgence of interest about STW generates myths. Governments could be induced to introduce on a large scale work-sharing schemes even in institutional landscapes in which they are not likely to operate efficiently.

Among the issues: Why are STW schemes used in some countries and not in others? Which design features of STW make them more palatable for employers and workers? Are there relevant interactions with other institutions, protecting workers against labour market risk that could possibly enhance their role in promoting work sharing throughout recessions? And how large are deadweight losses associated with STW schemes?

In the next sections, we will address these issues providing preliminary answers drawing on evidence before, during, and after the Great Recession. Our starting point must be an 
assessment of the objectives of STW and its likely interactions with other institutions. Before going to the data we need some guidance from economic theory.

\section{Some Theory: STW and other institutions}

The stated goal of STW is to encourage firms to adjust labour in response to adverse shocks by reducing hours worked per employee rather than by implementing layoffs. In presence of production technologies allowing for some substitutability in the labour input between the number of employees and the number of hours worked per employee (Rosen, 1985; Fitzroy and Hart, 1985), reductions in labour costs are typically accommodated by reducing the number of workers rather than by work-sharing, that is, lower hours (and weekly wages) for all the employees. This bias towards layoffs can be readily characterised by considering the cost minimization problem of a firm facing exogenous variations in the demand for its product.

Suppose that firms produce output, $y$, using only labour which requires some combination of workers, $n$, and hours of work, $h$. In particular, assume that the production function is multiplicatively separable, that is, given by $y=n^{\alpha} h^{\beta}$ where $0<\alpha, b \leq 1$. This functional form allows for decreasing marginal returns to both hours (working longer hours reduces productivity at the margin) and workers (there may be constraints in office space or in work organization reducing the marginal contribution to production of the last worker being hired). It also encompasses the case where reductions in hours worked per employee are isomorphic to reductions in the number of employees from the standpoint of production technologies. This happens to be when $\alpha, b=1$. In this case the curve displaying the same level of effective labour input, the so-called isolabour curve, is a hyperbola as depicted in Figure 3.

\section{Figure 3}

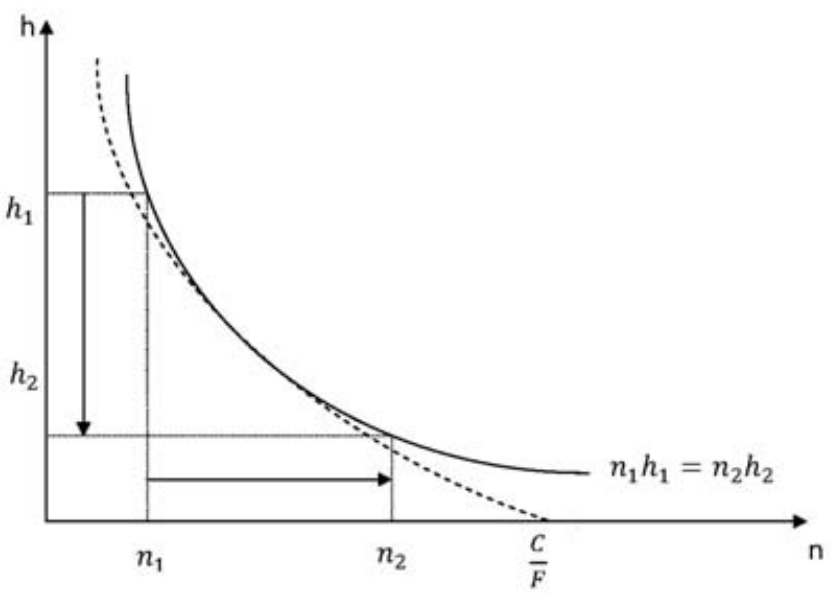

Labour costs typically feature not only variable costs (the hourly wages, $w$ times the number of hours worked) but also fixed costs per worker, $F$, e.g., related to the training of workers, and their office space, i.e.:

$$
\mathrm{C}=\mathrm{n}(\mathrm{F}+\mathrm{wh})
$$

The dotted curve in Figure 3 displays all the combinations of hours and workers corresponding to the same labour costs or the isocost for labour curve. Per any given level of 
output, the optimal choice of the firm will combine hours and workers in such a way as to attain the targeted output level at the lowest costs, that is, where the isocost curve is tangent to the isolabour curve corresponding to this level of output. The formal derivation of this condition is provided in Annex 1 for the general case where higher wages have to be paid to convince the employees to work longer hours, i.e., where $w=w(h)$ and $w^{\prime}>0$. It obtains the (conditional) demands for hours and workers

$$
\mathrm{h}=\frac{\beta}{\propto} \frac{\mathrm{F}}{\varepsilon_{\mathrm{h}}^{\mathrm{w}}},
$$

and

$$
n=\bar{y}^{\frac{1}{\alpha}}\left(\frac{\beta}{\alpha} \frac{F}{\varepsilon_{n}^{w}}\right)^{\frac{-1}{\alpha}}
$$

respectively, where $\varepsilon_{h}^{w}$ denotes the elasticity of wages to hours of work. Notice that the optimal choice of hours of the firm is independent of the targeted scale of production, $\bar{y}$, while this is not the case for the choice of workers. In other words, changes in the scale of production affect the number of workers, but not the hours of work per employees. This is consistent with the observation in several industries of broadly the same number of hours worked per employee independently of the size of the firms. By the same token, a reduction in costs required to match a decline in the targeted output level associated with an adverse shock, will be accommodated by reducing the number of workers rather than by reducing the hours of work. This result, also formally proved in Annex 1, stems from the production technologies allowing for substitutability between hours and workers as well as the presence of fixed costs per worker.

This bias of employment adjustment toward workers leads to "excessive" job losses (Hall and Lazear, 1984; Farber, Hall and Pencavel, 1993; Hall, 1995) during recessions or in presence of shocks temporarily reducing the demand for specific industries and firms. It would instead be both "more equitable and efficient" (Reid, 1985) to reduce hours of work for everybody. The inefficiency of this type of adjustment is related to the different degree of risk aversion of workers and firms. Workers are risk averse and would be better off by working less hours (and earning less) during downturns, but avoiding job losses. Employers having access to capital markets are instead risk neutral and could in principle "sell" an insurance to their workers, which avoids job losses in exchange for lower wages throughout the employment relationship. An additional source of inefficiency of labour adjustment carried out along the extensive margin rather than the intensive margin of hours of work is related to the fiscal costs of dismissals (Burdett and Wright (1989); van Audenrode (1994)): in presence of unemployment benefit systems, employers laying off their workers exert a negative fiscal externality, by imposing a higher expenditure for unemployment benefits.

While it is possible to find arguments for work-sharing arrangements purely on efficiency grounds, this does not imply that such arrangements should be offered by the public sector. Private contractual arrangements between workers and employers can, by themselves, counteract the intrinsic bias of labour adjustment toward layoffs, by including contingency provisions allowing for hours adjustment in response to changes in demand conditions. The Working Time Accounts introduced in Germany in the mid-1990s are one of these private contractual arrangements and are described in some detail in Section 4. The case for state 
intervention can only be made on second-best grounds. In many countries, collective bargaining over pay and working conditions is centralized at the national or industry level. Even when decentralized, plant-level, bargaining is allowed, it rarely involves small units, where typically there are no collective organizations of workers at the workplace. All this prevents introducing work sharing arrangement at the plant level. At the same time, a centralized collective agreement typically features minimum levels of pay, the definition of "standard" hours and norms for overtime pay and shifts to be applied to all firms represented at the bargaining table. This centralized agreement could, in principle, include contingency provisions reacting to aggregate shocks, but it is very unlikely to deal with idiosyncratic shocks and cannot take into account of firms' specificities as to the degree of substitutability between hours and workers in the production process.

Another factor that stands on the way of private STW arrangements is the imperfection of capital markets. Small firms, in particular, may have limited access to financial markets. Thus, they could face liquidity constraints when required to offer insurance to their workers by keeping them on their payroll even in presence of adverse shocks (Cahuc and Carcillo, 2011). This problem is clearly particularly relevant under financial crises like the Great Recession.

A publicly operated STW system, however, involves the same moral hazard problems arising in the provision of unemployment insurance. Workers and employers may collude in extracting payments from the state even when incentives to hours reductions would not be required to avoid layoffs as the firm is no longer facing a negative demand shock. Appropriate design features of these schemes, such as "experience rating" (Feldstein, 1976; Blanchard and Tirole, 2007), that is, imposing to employers making use of STW to contribute more than the employers not drawing on public resources, could reduce the risk of abuse of these schemes. However, full experience-rating may not be feasible or optimal (Cahuc and Zylberberg, 2008) precisely for the same constraints that prevent a fully private provision of work sharing arrangements, notably in small firms. Moreover, raising the costs of STW for employers, forcing them to internalize at least partly the fiscal externality they impose on other firms and workers has the consequence of reducing the use of STW, hence the extent of hours adjustment in presence of demand shocks.

Macro models provide a case for a publicly operated STW as a device to prevent wage deflation in the context of temporary slowdowns in economic activity. STW contributes to avoiding a spiral of declining employment, wages and hence aggregate demand which would cause a deeper fall in output. This suggests that STW should be made particularly attractive for firms under downturns in order to maximize take-up. One way to reconcile this objective with the goal of reducing moral hazard is to allow for cyclically adjusted employers' contributions: payroll taxes financing STW should decline during downturns and increase during upturns.

The discussion above indicates that the design features of STW are very important in affecting both its success among employers and workers and its efficiency properties. In order to gauge which factors are likely to have more of an impact on the demand for STW, it is useful to remind the cost minimizing choice of hours: $h=\frac{\beta}{\propto} \frac{F}{\varepsilon_{h}^{W}}$. This equation states that hours reductions could be encouraged when labour costs faced by the employers become more responsive to changes in working time, notably when wages per worker for the 
employers decline more than proportionally with the reduction of hours of work. This is precisely the task which is given to STW. From the standpoint of employers, these schemes should increase the cost savings associated with reducing working time, while, from the standpoint of employees, they should minimize the fall in take-home pay. Notice further that STW schemes allowing for declines of hourly labour costs when hours of work are reduced are likely to have more of an impact in presence of relatively large fixed costs per worker, $F^{1}{ }^{1}$ A significant component of these fixed costs is represented by employment protection legislation. The predicted role of STW in biasing labour adjustment towards hours reductions is also stronger the greater the technology parameter $\beta$ (the elasticity of output with respect to hours) and the lower the elasticity of output with respect to the number of workers in the firm.

Many of these factors affecting the demand for STW are firm-specific. Production technologies to start with, hence the substitutability of layoffs with hours reductions, are likely to vary across firms. The responsiveness of wages to hour reductions is also likely to be different across production units, as workers may have different preferences over the labour-leisure trade-off. An additional source of variation in the use of subsidized hours adjustment is related to institutional interactions. In particular, employment protection legislation (or experience-rated unemployment benefits) increasing the relative costs of external adjustment can promote work-sharing, while generous unemployment benefits paid by all employers and workers (not only those making use of them) would operate in the opposite direction. Finally, as pointed out by Cahuc and Carcillo (2011), cultural traits may be important in the demand for STW.

We will document below that there is significant cross-country heterogeneity in the design of STW. We will also show that this heterogeneity accounts for a substantial portion of the cross-country and time-series (to the extent that the design of these schemes has been adjusted) variation in take-up rates.

\section{Key design features of STWs}

It is misleading to consider STW as a fairly homogenous scheme operated at different degrees in a number of countries. There are indeed substantial cross-country differences in crucial design features of STW, making these schemes hardly comparable along a single dimension. These differences can be documented by drawing on a survey recently carried out by the OECD and on an excellent work done by Alexander Hijzen and Danielle Venn in characterising these institutional differences (Hijzen and Venn, 2010). ${ }^{2}$ Table A1 and A2 in Annex 2 summarize the institutional details provided by the OECD survey. We confine ourselves herein to defining some synthetic indicators of STWs along the dimensions which are more relevant according to economic theory. All indexes are normalized to be in the $0-1$ interval where 1 denotes the strictest.

Our first indicator measures the strictness of eligibility criteria. It is defined by counting all the categorical or procedural conditions required to activate a STW scheme at the

\footnotetext{
${ }^{1}$ To see this, take the first derivative of the conditional demand for hours with respect to $\varepsilon_{h}^{w}$

${ }^{2}$ For the EU-27, see also the comprehensive overview by Arpaia et al. (2010).
} 
workplace. Some countries require that the use of short-time work is supported by a collective agreement or is at least approved by the unions when white collars are involved. In some countries (e.g. Germany) worker councils can initiate STW. Other countries require that only workers otherwise eligible to unemployment insurance are involved (recall that one of the arguments for STW was the desire to minimize the fiscal externalities associated with unemployment insurance) and only if they have a minimum contribution record. This prevents many workers with fixed-term contracts or part-time workers with few working hours to be eligible to STW. In the course of the Great Recession, these eligibility criteria were relaxed for workers with atypical contracts in many countries. An account of these reforms is offered in Annex 2. Other eligibility conditions relate to the requirement that the scheme is applied at least to a significant portion of the total workforce (it should be a work sharing device) and that the reduction exceeds a minimum fraction of the standard working hours. The rationale behind these minimum requirements is to allow only firms facing serious falls in demand to have access to STWs. Ten out of the twenty countries having STW feature minimum hours requirements. Formal "justification of economic need" is also often required. This means that firms must prove that they are facing negative demand shocks, e.g. by documenting some reduction in production or sales. It is a condition aimed at reducing deadweight losses.

Our second index captures the strictness of entitlement criteria, that is, the conditions that have to be fulfilled by the firm or worker in order to continue to be eligible to STW. These provisions may include the obligation for the employer to provide training to short-time workers (as in the Czech Republic, Hungary, Netherlands and Portugal), the definition of a restructuring plan (Belgium, Italy, Luxembourg, Poland and Spain), and the absence of dismissals throughout the period in which the firm is using STW (as in Austria, France, Hungary, Netherlands, New Zealand and Poland). Some conditions may also apply to the employees: for instance Denmark, Finland, Norway, Germany and Spain include job search requirements for the workers involved similar to those involving workers receiving unemployment benefits, although these workers are still formally on the payroll of the firm. As in the eligibility index, we simply add up these requirements and normalize them to be in the zero-one interval. Needless to say, some of these conditions are rather poorly enforced: job search requirements are, for instance, rarely enforced, notably during downturns.

The third index measures the cost to the employers of STW. In some countries, STW are mainly funded via general tax revenues, while in others they are financed by social security contributions. Our measure considers the share of the running costs of STW which are paid by the employers in the first month of activation of the scheme. Firms participate in the costs of STW benefits either by paying a part of the working costs for the hours not worked (e.g. France, Hungary, Japan, Germany, Poland, Portugal, Netherlands and the Slovak Republic) or by paying full wages for an initial period (e.g. Norway and Sweden). In some of these cases firms are obliged to pay the full amount or a part of the social security contributions for the hours not worked (e.g. Germany) which discourages abuse of STW. In other countries (e.g. Italy and the US) bonus-malus arrangements are also envisaged, thereby employers making use of the scheme have to pay higher contributions (this way of partly internalizing the fiscal externalities associated with STW is also defined as "experience-rating"). Our index multiplies the share of total costs by the STW replacement rate (a measure of the total costs) adjusted by the maximum duration of the benefits. In the 
majority of the countries the replacement rate for the hours not worked equals the replacement rate of the unemployment benefits. Since the average reduction of working hours is usually well below 100 per cent, workers which participate in STW schemes are usually better off than their unemployed counterparts, in addition to be still formally attached to the firm. The costs for the employer are also increasing in the extent of the hours reduction. In some countries, hours reductions can be as high as 100 per cent, putting the worker in a condition which is similar to a leave or a temporary layoff, although the worker is still on the firm's payroll. In the course of the Great Recession most countries relaxed the restrictions on the maximum reduction of working hours. The exceptions are in this case Austria, Canada, Luxembourg and the Netherlands. Overall, our indicator covering the costs to the employers can be interpreted as the inverse of the subsidy component (for the employer) of the STW.

Finally we include a measure of the responsiveness of STW replacement rates to hours reduction. While average labour costs decline, the cost per working hour tend to increase with the reduction of working hours (see Box 1, Box 2 and Crimman et al., 2010) unless short-time work is completely subsidised. The elasticity of STW to hours is given by the ratio of the replacement rate at the maximum hours reduction to the replacement rates at the minimum hours reduction allowed by the scheme. This captures the extent to which workers' incomes are affected by hours reduction, hence potential pressures for compensation in terms of increased hourly wages by the employees. This ratio is then multiplied by the difference between the maximum and the minimum hours reductions, both expressed as ratios to the length of the standard working week. With the exception of Finland, all countries have a maximum duration period, which has been extended in the course of the crisis in many countries. The average duration period is 14 month in the OECD and the median is 12 months. Most countries which have introduced STWs during the Great Recession have relatively short durations, while those with a longer tradition usually allow firms to apply STW schemes for a longer period of time. 
Table 3: Summary Indicators of STW

\begin{tabular}{l|cccc}
\hline \multicolumn{1}{c|}{ Country } & $\begin{array}{c}\text { Strictness } \\
\text { eligibility } \\
\text { criteria }\end{array}$ & $\begin{array}{c}\text { Strictness } \\
\text { entitlement } \\
\text { criteria }\end{array}$ & $\begin{array}{c}\text { Cost to } \\
\text { employer }\end{array}$ & $\begin{array}{c}\text { Elasticity of } \\
\text { STW to hours }\end{array}$ \\
\hline Austria & 0.4 & 0.25 & 0.24 & 0.50 \\
Belgium & 0.3 & 0.13 & 0.02 & 0.69 \\
Canada & 1.0 & 0.00 & 0.00 & 0.33 \\
Czech Republic & 0.4 & 0.25 & 0.06 & 0.59 \\
Denmark & 0.6 & 0.13 & 0.04 & 0.43 \\
Finland & 0.7 & 0.25 & 0.00 & - \\
France & 0.4 & 0.25 & 0.12 & 0.74 \\
Germany & 0.6 & 0.25 & 0.23 & 0.56 \\
Hungary & 0.6 & 0.50 & 0.27 & 0.79 \\
Ireland & 0.4 & 0.25 & 0.00 & 0.26 \\
Italy & 0.2 & 0.25 & 0.22 & 0.81 \\
Japan & 0.6 & 0.00 & 0.00 & 0.65 \\
Korea & 0.7 & 0.00 & 0.00 & 0.92 \\
Luxembourg & 0.4 & 0.25 & 0.10 & 0.44 \\
Netherlands & 0.6 & 0.50 & 0.62 & 0.27 \\
New Zealand & 0.2 & 0.25 & 0.35 & 0.10 \\
Norway & 0.6 & 0.25 & 0.15 & 0.45 \\
Poland & 0.4 & 0.50 & 0.11 & 0.48 \\
Portugal & - & 0.25 & 0.17 & 0.71 \\
Slovak Republic & 0.4 & 0.00 & 0.00 & 0.70 \\
Spain & 0.4 & 0.50 & 0.56 & 0.47 \\
Switzerland & 0.5 & 0.00 & 0.00 & 0.73 \\
Turkey & 0.6 & 0.00 & 0.00 & 0.46 \\
United States & 1.0 & 0.00 & 0.00 & 0.29 \\
\hline & & & & \\
\hline
\end{tabular}

Notes: Cost to employer $=$ STW NRR $\times$ (Maximum Duration/28 months) $\times$ Degree of Experience Rating; Elasticity of hours to STW = (Max STW NRR over Min STW NRR)x(Max Hours Reduction - Min Hours Reduction); NRR is the net replace ment rate; Eligibility criteria includes minimum hours reduction larger than $10 \%$, provision of justification of economic need, social partner agreement and workers being eligible for UB; Entitlement criteria include compulsory training, recovery plan, no dismissal and job search requirement for employee; degree of experience rating is computed as STW cost for employer over total STW cost.

Source: own calculations based on data from Alexander Hijzen and Danielle Venn, 2010 OECD Working Paper

Table 3 documents substantial cross-country differences in these key design features of STW. In terms of eligibility conditions, the least restrictive systems are those of Italy and New Zealand while the most restrictive are in North-America. Hungary, Netherlands, Poland and Spain are the most restrictive in entitlements rules. Two of the latter group of countries are also forcing employers to internalize more than 50 per cent of the costs related to the activation of the program in their firm. Notice that in a number of countries firms do not participate at all in the costs of STWs (Canada, Finland, Ireland, Japan, Korea, Slovak Republic, Switzerland, Turkey and the US). Finally, Korea and Italy are the two countries where the replacement of the previous earnings offered by STW declines only very mildly with the scale of hours reductions preventing a strong reduction in take-home pay. More 
insights as to the German and Italian STW schemes, the two largest in terms of take-up rates, are offered in the boxes below.

How do these features affect the demand for STW?

The demand for STW is likely to be affected by the specific features of each STW scheme, notably the eligibility and entitlement conditions and the financial contribution requested to the employers making use of the programme or degree of experience-rating. The above theoretical considerations suggest that short-time work is an institution which could be more popular and widely used in countries where the replacement rates offered by STW are only mildly declining with hours reductions. Institutional interactions are also important: strict employment protection legislation and collective bargaining institutions highly constraining downward wage adjustment should increase the demand for STW which are likely to be less widely used in presence of generous UB systems.

Table 4 displays estimates of the STW take up rates (defined as programme participants over the labour force), by pooling cross-country and (quarterly) time-series observations. In particular, we investigate whether take-up rates are correlated with the strictness of EPL, the centralization of collective wage bargaining institutions, the generosity of UB, as well as with the design features of STW which were characterised above.

The estimates are carried out by using quarterly observations from Q1 2003 to Q1 2010 (whenever available ${ }^{3}$ ) over twenty countries (Austria, Belgium, Canada, Czech Republic, Denmark, Finland, France, Germany, Hungary, Ireland, Italy, Japan, Luxembourg, Netherlands, Norway, Poland, Portugal, Slovak Republic, Spain and Switzerland) and controlling for macroeconomic conditions (captured by quarterly GDP growth rates). EPL, UB and the centralization indexes also vary across countries and over time (although only at yearly frequencies), while the STW design features, which were described above, have only a cross-sectional variation in that they capture the characteristics of these schemes at $0109^{4}$

\footnotetext{
${ }^{3}$ Original data are provided by Alexander Hijzen and Danielle Venn (2010 OECD) but have been extended by Cahuc and Carcillo (2011).

${ }^{4}$ Annex 2 displays results of a regression confined to Q109 to Q210 period. Results are broadly in line with those displayed in Table 4.
} 
Table 4: Determinants of STW take-up rates -- Regression results
(1)
(2)
(3)
(4)

(5)

STW take-up rate

\begin{tabular}{|c|c|c|c|c|c|}
\hline GDP Growth [t-1] & $\begin{array}{c}-0.139 * * * \\
(0.0492)\end{array}$ & $\begin{array}{c}-0.139 * * * \\
(0.0527)\end{array}$ & $\begin{array}{c}-0.177 * * * \\
(0.0482)\end{array}$ & $\begin{array}{c}-0.186^{* * *} \\
(0.0538)\end{array}$ & \\
\hline Employment Protection Index & & $\begin{array}{c}0.294^{* *} \\
(0.138)\end{array}$ & $\begin{array}{c}1.035^{* * *} \\
(0.219)\end{array}$ & $\begin{array}{c}1.173^{* * *} \\
(0.308)\end{array}$ & $\begin{array}{c}1.416^{* * *} \\
(0.289)\end{array}$ \\
\hline UB net replacement rate & & $\begin{array}{c}-0.0179 * * \\
(0.00864)\end{array}$ & $\begin{array}{c}-0.0504 * * * \\
(0.00997)\end{array}$ & $\begin{array}{c}-0.111 * * * \\
(0.0192)\end{array}$ & $\begin{array}{c}-0.112 * * * \\
(0.0177)\end{array}$ \\
\hline Bargaining centralization index & & $\begin{array}{c}0.346 * * * \\
(0.0853)\end{array}$ & $\begin{array}{c}0.265 * * * \\
(0.0762)\end{array}$ & $\begin{array}{c}0.484 * * * \\
(0.0936)\end{array}$ & $\begin{array}{c}0.617^{* * *} \\
(0.0886)\end{array}$ \\
\hline Strictness of eligibility criteria & & & $\begin{array}{c}-1.395^{* * *} \\
(0.379)\end{array}$ & $\begin{array}{r}-0.0522 \\
(0.646)\end{array}$ & $\begin{array}{c}0.657 \\
(0.607)\end{array}$ \\
\hline Strictness of entitlement criteria & & & $\begin{array}{c}-6.200 * * * \\
(0.809)\end{array}$ & $\begin{array}{c}-4.566 * * * \\
(1.604)\end{array}$ & $\begin{array}{c}-6.240 * * * \\
(1.516)\end{array}$ \\
\hline Cost to employer & & & & $\begin{array}{c}-2.193^{*} \\
(1.145)\end{array}$ & $\begin{array}{l}-1.496 \\
(1.066)\end{array}$ \\
\hline STW net replacement rate & & & & $\begin{array}{c}0.0468 * * * \\
(0.0144)\end{array}$ & $\begin{array}{c}0.0462 * * * \\
(0.0133)\end{array}$ \\
\hline STW elasticity to hours & & & & $\begin{array}{c}-0.811 \\
(0.570)\end{array}$ & $\begin{array}{l}-0.375 \\
(0.520)\end{array}$ \\
\hline Constant & $\begin{array}{c}0.874 * * * \\
(0.0692)\end{array}$ & $\begin{array}{c}0.511 \\
(0.501)\end{array}$ & $\begin{array}{c}3.008 * * * \\
(0.545)\end{array}$ & $\begin{array}{c}2.561^{* * *} \\
(0.811)\end{array}$ & $\begin{array}{c}1.744 * * \\
(0.861)\end{array}$ \\
\hline Quarterly x Year Fixed Effects & No & No & No & No & Yes \\
\hline bser & 349 & 325 & 322 & 285 & 292 \\
\hline -squared & 0.023 & 0.162 & 0.348 & 0.441 & 0.590 \\
\hline
\end{tabular}

Notes: standard errors in parentheses. ${ }^{* * *},{ }^{* *},{ }^{*}$ denote the $1 \%-, 5 \%-$, and $10 \%$-significance levels, respectively. Bargaining centralization index represents the dominant level(s) at which bargaining takes place (missing after 2007, we make the strong assumption that value for 2008 and 2009 does not change). It takes the following values:

$5=$ national or central level

$4=$ national or central level, with additional sectoral / local or company bargaining

$3=$ sectoral or industry level

2 = sectoral or industry level, with additional local or company bargaining

1 = local or company bargaining

Adding Strictness of eligibility criteria reduces the size of the sample because it is missing for Portgual; adding Bargaining Centralization Index reduces the size of the sample because it is missing for Korea and Turkey; adding STW net replacement rate reduces the size of the sample because it is missing for Finland.

Source: own calculations on data from Alexander Hijzen and Danielle Venn, 2010 OECD Working paper, extended by Cahuc and Carcillo (2011); EPL, UB nrr and GDP growth from OECD; Bargaining centralization index from Visser (2009).

The table suggests that STW is not an institution which could be readily extended to countries with low employment protection. Generous unemployment benefit systems also tend to be associated with relatively low take-up rates, although this correlation is not 
always statistically significant. Thus, flexicurity arrangements seem to be a substitute for STW. Decentralized wage bargaining structures can also reduce the demand for STW.

Looking at the design features of STW, higher costs for employers and more restrictive eligibility and entitlement conditions are associated with lower take-up rates. This is hardly surprising, but confirms that many details of these institutions should not be overlooked and that simple comparisons across countries, not acknowledging these differences in design may be quite misleading. The devil is very much in the details here. Another factor positively affecting the demand for STW is the net replacement of previous earnings being offered, which buys workers' consensus to hours reductions. The responsiveness of STW to hours adjustment is, however, not significant, albeit this is an admittedly poor proxy for the responsiveness of labour costs to wage adjustment.

The effects implied by our estimates are quite sizeable. In order to give an idea of the magnitudes involved, the estimated coefficients imply that bringing Belgium to Germany in terms of eligibility conditions would reduce the take-up rate by 1.9 percentage points, halving its level from its peak of 4.4 during the Great Recession. Similarly reducing the replacement rate of Italy to the levels of Austria would reduce the take-up rate by 1.3 percentage points.

\section{Box 1: STW in Germany}

Short-time work has been widely applied in Germany to buffer economic shocks since the first oil price shock in 1973. At present, the German system envisages three kinds of short-time work:

1. Short-time work for economic reasons. The eligibility criteria for this type of STW is that a firms faces a temporary, unavoidable threat of losing employment due to economic factors or another unavoidable event (Social Code III, § 170). This type of STW is basically designed for adjustments in the course of the business cycle. About 90 per cent of STW in Germany referred to this category in 2009.

2. The so-called "Transfer-Kurzarbeit", for firms which face a permanent loss of employment due to restructuring measures at the firm level (Social Code III, $\S 216 \mathrm{~b}$ ). This type of short-time work was extensively used in Eastern Germany after German unification, when large parts of the industrial sector collapsed. Employees on "Transfer-Kurzarbeit" cannot be reemployed by the affected firm or by other affiliates of the enterprise benefitting from the transfers. This scheme should buffer structural adjustment, but cannot postpone it.

3. Short-time work for seasonal workers (Social Code III, § 175) which is mainly used in the construction sector and other "outdoor" branches of the economy. STW benefits for seasonal workers are only granted in the period from December 1 to March 31.

Employees are eligible to short-time work benefits if they contribute to social security and if their contract is not terminated. The reduction in working hours must imply an earning loss of at least 10 per cent. STW benefits are paid by the Federal Employment Services, which adds to the hourly wage times the hours worked which is offered by the firm a transfer enabling the worker to earn on the hours reduction a fraction of the hourly wage which is equal to the replacement rate offered by unemployment benefits. For an earner with one dependent child this replacement rate is 67 per cent, for an earner without dependents it is 60 per cent.

A firm is eligible for short-time work for economic reasons if it claims that the business conditions have temporarily deteriorated and that all other flexibility measures (e.g. reduction of overtime hours and workingtime accounts) have been already utilized. Before the Great Recession, it was also necessary that at least onethird of the employees had been affected by an income loss of at least ten per cent due to the reduction of working hours. There also job search requirements like those applied to unemployment benefits recipients. 
Firms participate in the costs of the reduced working hours via contributions to the social security system (pensions, health insurance unemployment insurance). Before the Great Recession, employers had to pay 80 per cent of the social security contributions for the working hours reduced. Note that the social security contributions of employers and employees reach almost 40 per cent of a gross salary in Germany. Since February 1, 2009, 50 per cent of these costs of the firm for the working hours reduced are reimbursed by the Federal Employment services. Moreover, the Federal Employment Services reimburses 100 per cent of the costs if firms rely for more than 6 month on STW from July 1, 2009 to March 31, 2012. Finally, the Federal Employment Services covers also 100 per cent of the costs if the employees affected by STW participate in approved training measures. Nevertheless, only about 20 per cent of the employees affected by STW participate in those training measures.

Figures $A$ and $B$ illustrate the cost of the program for an employer before and after the reform of the system, in case of an employee with a standard full-time contract and a gross salary of 3,000 EURO per month, which corresponds roughly to the average salary in Germany. The total amount of social security contributions is 19,725 per cent for the employer, so that total labour costs amount to $3,591.75$ EUROs. Social security contributions of the employee amount to another 20,625 per cent for the employee or 618.75 EUROs. Under the old scheme, the employer had to pay 80 per cent of the total security contributions of the employer and the employee per each working hour reduced. In case of a reduction of 100 per cent of the working hours, this would leave the employer in our example with a cost of 968.4 EUROs or 27 per cent of the total labour costs of a full-time employed worker. After the reform, this cost is reduced to 482.4 EUROs or 13.2 per cent of the costs of a full-time worker.

As shown by figure $A$, total costs per working hour increase disproportionally with hours reductions: under the old scheme, the firm has to pay 26 EUROs per hour instead of 23.3 EUROs per hour if it reduces the average working time by 30 per cent, 29.6 EUROs if it reduces it by 50 per cent and 646 EUROs if it reduces it by 99 per cent. Under the new scheme, the cost per working hour stands still at 335 EUROs if the working time is reduced by 99 per cent. Note that the average reduction of working hours of firms which take-up STW has been reduced from 55 per cent before the Great recession to 34 per cent in the second quarter of 2010.

Figure A - Labour costs and STW

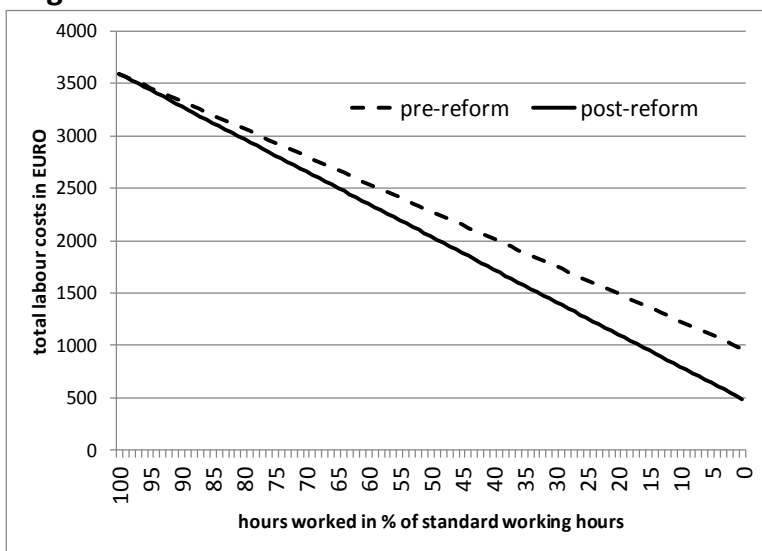

Figure B - Labour cost per hour and STW

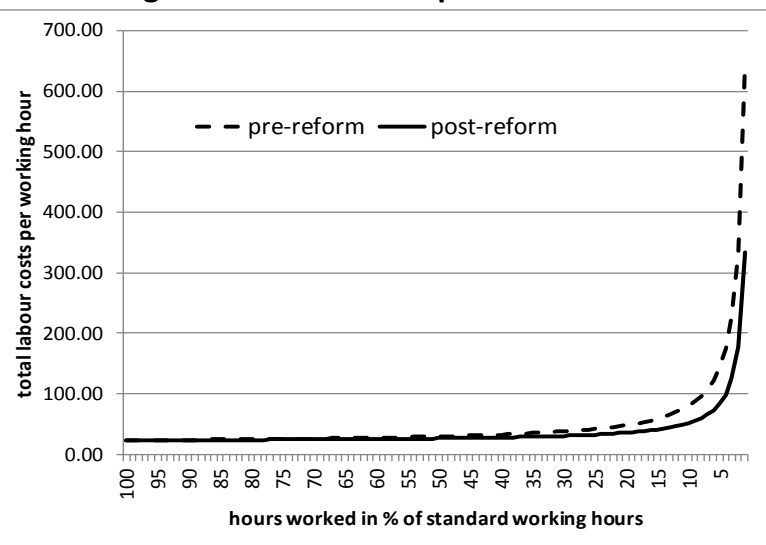

Source: Own calculation based on data from the German social security systems. See Crimman/Wiesner (2009) for similar calculations.

\section{Box 2: The Italian STW}

Italian short-time work scheme can be defined as a wage guarantee fund based on two main pillars, "Cassa Integrazione Guadagni Ordinaria" (CIGO) and "Cassa Integrazione Guadagni Straordinaria" (CIGS), and on a third pillar more recently introduced, "Cassa Integrazione in Deroga (CIGD). CIGO is applied in case of a temporary reduction of activities related to short-term problems. It covers blue and white-collar workers in construction and manufacturing sectors employed in firms with more than 15 employees and workers in the service sector of firms with more than 50 employees. CIGS covers a smaller range of sectors than CIGO. It deals with the restructuring of plants, reorganisation of production, prolonged crisis or bankruptcy procedures. It has a greater coverage of service sectors than CIGO. CIGD is aimed at extending the duration of CIGS or involving firms that are not covered. During the Great Recession, CIGD was temporarily extended to small and mediumsized firms in the tertiary sector without requiring that employers and employees of these firms had paid 
contributions in the past to this scheme. Indeed, CIGD is paid out of General Government revenues. Often firms go through the entire sequence: CIGO, CIGS and then CIGD, which is paradoxically the least costly for the employer of the three.

Both $\mathrm{CIGO}$ and $\mathrm{CIGS}$ are quite generous in principle as they are supposed to replace about 80 per cent of previous earnings. However, there is a rather low monthly ceiling (in 2009, maximum net amount was 840,81 EUROs per month for workers with a monthly salary below 1.931,86 EUROs per month and 1.010,57 EUROs per month for workers with a higher salary). Notice that 5.84 per cent of this gross wage should be paid by the worker to social security. The maximum duration of CIGO is 12 months, while for CIGS it is 12 months in case of company crisis, 18 months for bankruptcy and 24 months in case of restructuring. In any case, $\mathrm{CIGO}$ and $\mathrm{CIGS}$ altogether cannot exceed a period of 36 months over 5 years. In principle participation to CIGO and CIGs is conditional on not refusing a suitable job and on attending training programmes, but this requirement is rarely enforced.

In order to benefit from $\mathrm{CIGO}, \mathrm{CIGS}$ and $\mathrm{CIGD}$, prior consultation with trade unions is required: unions can interfere with decisions of firms not only about how many workers to put on the short-time work scheme, and on the extent of hours reductions, but also on the characteristics of the workers involved.

Contributions paid by employers increase with the size of firms (1.90per cent of wages for firms with less than 50 employees and 2.20 per cent for those with more than 50 employees). Moreover, companies using $\mathrm{CIGO}$ have to pay an additional contribution of 8 per cent of the wage supplement if they employ more than 50 workers, 4 per cent if less. However, if the employer can prove that the reduction of working hours was due to exogenous reasons, this experience-rated component is not applied. Also CIGS involves some experiencerating, but in the first 24 months it is lower $(4.5$ per cent or 3 per cent for companies with less than 50 employees). This contribution increases to 9 per cent ( 6 per cent for small firms) after 24 months. Notice that, unlike in Germany, social security contributions are paid only for actual hours worked.

Figures $C$ and $D$ illustrate respectively the total labour cost and hourly labour cost of participation of firms to CIGO. We consider an individual with no children earning the average production worker gross wage of 2.182 EUROs per month, including social security contributions (OECD Taxing Wages 2008-2009). Since the employer has to pay no social security contribution for hours not worked, the cost is simply represented by the wage paid for the actual hours worked plus the experience-rated contribution, when required. Suppose hours worked are reduced by 50 per cent. In this case the employer pays 1,171 EUROs for the hours actually worked and a contribution of 80.85 EUROs for hours not worked (8 per cent of 1010.57 EUROs, the maximum STW payable by law). This corresponds to a cost of 14.65 EUROs per hour. If average working time is reduced by 99 per cent, the cost increases to 64.16 EUROs per hour. However, if the firm is exempted from experience-rating (as for most firms under CIGS under the Great Recession) hourly costs are flat in hours reductions at 13.64 EUROs and total costs can go all the way down to zero. In the case of the Cassa in Deroga, there is no cost for the employer for the hours of short-time work. Thus, unlike in Germany, there is a strong convenience for firms to bring hours of work all the way down to zero. During the Great Recession, the bulk of hours reductions occurred in CIGD. From accounting for less than 5 per cent of the total hours of STW, Cassa in Deroga had climbed to one third of the total hours of STW by February 2011 and was still rising six quarters after the end of the recession.

Figure C: Labour Cost and STW

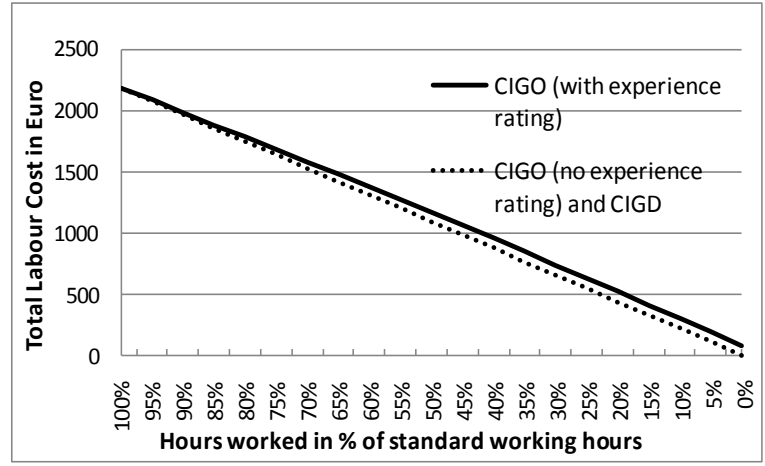

Figure D: Hourly Labour Cost and STW

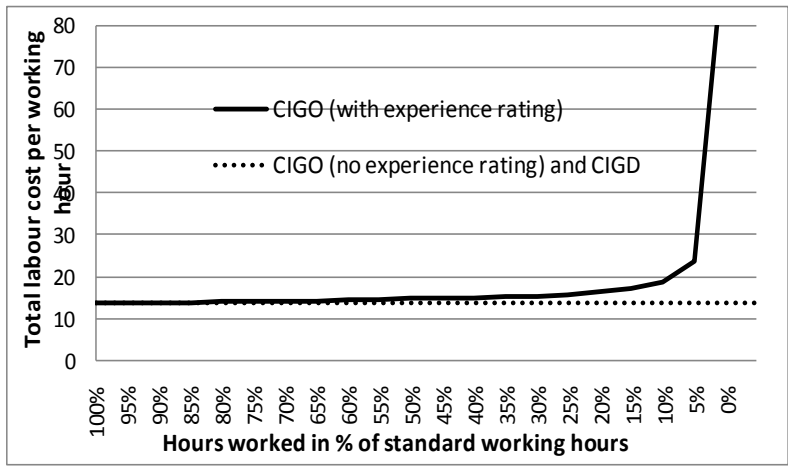

Source: own calculations based on information from the Italian National Institute of Social Insurance. 


\section{An Evaluation}

\subsection{Responsiveness to Cyclical Conditions and Targeting}

As we have seen, STW take-up rates are strongly affected by the generosity of these schemes for the employer and partly also for the employees. Thus a high take-up rate may point to high fiscal costs, borne by the general taxpayer, and does not necessarily imply that the scheme is cost effective.

As argued in Section 2, short-time work aims at counteracting the bias of labour adjustment towards workers, but at the costs of inducing an inefficient combination of hours and employees. For this reason STW must operate temporarily to induce adjustments along the intensive margin in presence of transient shocks. If they are long lasting and are used to deal with structural redundancies, these schemes become a device to increase the duration of unemployment benefits, increasing rather than reducing the fiscal externalities of employment adjustment.

An additional reason for having STW operating only as a temporary shock absorber is that this institution obstructs restructuring associated with technological progress and structural change by freezing workers into low productivity jobs. As discussed in Box 3 , this reduces longer term growth by making it more difficult to attain the productivity gains associated with the reallocation of workers from low-productivity to high productivity jobs. There are better instruments, such as unemployment benefits and subsidies to job creation, dealing with the long term process of technological change and creative destruction.

\section{Box 3: Job Reallocation and Short-time Work}

The long-run inefficiencies associated with a prolonged use of STW can be better understood by considering a dynamic model of the labour market with search frictions and gross job reallocation at the equilibrium job search. In this class of models, unemployment has a (socially) efficient function to play in selecting the most efficient units and in reducing congestion in the job openings market. Search frictions generate rents for employers and workers, which are split - in the tradition of Mortensen and Pissarides (1994) - by a Nash bargaining rule. This wage setting regime implies that separations are always jointly privately efficient (for the employers and the workers) whenever match productivity falls below an endogenously determined reservation productivity threshold. This does not mean that they are socially efficient. In presence of a very strong bargaining power of workers for instance, there can be more unemployment than socially optimal. Conversely a too strong bargaining power of employers may induce too little unemployment in that it becomes very difficult to fill vacancies when there are too few jobseekers around.

Short-time work funded out of general Government revenues can be framed in this context as a transfer to firms experiencing negative shocks to productivity, conditional on keeping their jobs alive, and funded by a payroll tax on highly productive firms. The effect of STW is isomorphic to employment protection legislation in that it forces the reservation productivity below the levels that would prevail otherwise. STW reduces separations by lowering the outside opportunity of employers (who have to give up a subsidy in case the job is destroyed) and workers (who face lower job finding rates when unemployed). Notice that this result does not depend on the nature of the shock. The level of the reservation productivity is affected by the frequency of shocks, but STW reduces this 
reservation productivity independently of the frequency at which shocks to idiosyncratic (or aggregate) productivity occur. In other words, STW, just like EPL, is a labour hoarding device, reducing average labour productivity. As the value of a job for an employer is reduced by these institutions, STW negatively affects not only job destruction, but also job creation rates, with ambiguous effects on unemployment. Thus, STW cannot remedy the social inefficiencies related to a suboptimal distribution of bargaining power between workers and employers. At the same time, the unambiguous effect of STW is that it reduces job reallocation.

Suppose, for simplicity, that unemployment (employment) is the same with and without STW. It follows from the above that aggregate output is lower in presence of STW: there will be more low productivity and less high productivity jobs in this scenario than when this institution is not present. These dynamic inefficiencies associated with STW are even larger when we allow for technological progress embodied in new jobs (Caballero and Hammour, 1996). As new jobs start up being more productive than continuing jobs, institutions reducing job reallocation negatively affect economic growth. The policy implication is that policies trying to reduce unemployment should act on the job creation rather than on the job destruction margin. Subsidies to job creation are better suited than STW as they can reconcile the task of containing unemployment with that of increasing growth.

Overall, there is no case for STW when consideration is made of the creative destruction processes associated with job reallocation. Subsidies to firms conditional on avoidance of job destruction are also bound to be ineffective in reducing unemployment except in presence of a temporary negative aggregate shock. A transient shock may make many jobs unviable inducing a large wave of job destruction. If the shock turns out to be temporary and STW are removed after the shock, than the effects of this measure on the job destruction margin will outpace those on job creation. Provided that STW is also temporary, it therefore could contribute to reducing unemployment during downturns.

A case for STW can also be made in presence of rigid wages, preventing wages to be renegotiated in case of negative productivity shocks. Under wage rigidity, all separations are inefficient from the standpoint of the worker, who would therefore always vote for institutions postponing layoffs, even in presence of EPL. Employers would also favour the introduction of STW but only in presence of EPL, insofar as it prevents having a negative surplus in the job continuation region. Clearly, the support of individual employers would be stronger the less costly is STW, that is, the less this institution is experience-rated.

Wage rigidity itself can be endogenized in this context, as done by Boeri et al. (2008) allowing for centralized collective bargaining institutions setting floors to wage bargaining and preventing adjustment of wages to idiosyncratic shocks. In presence of centralized wage bargaining, the crucial issue is how frequent are wage renegotiations. Indeed also collective bargaining institutions react to aggregate shocks -- such as an overall productivity decline, by allowing for some wage adjustment, which in turn reduces layoffs. The lower the frequency of bargaining, the greater is the role of STW.

STW in presence of rigid wages is therefore mainly a device to prevent or reduce the scope of downward wage adjustment or to compensate for its absence in case of negative productivity shocks. There is a clear constituency supporting it, notably workers at the low productivity threshold. Employers would also favour STW when i. EPL is rather strict and ii. collective bargaining occurs at relatively low frequencies. Notice that the presence of wage rigidity by itself does not create a demand (of employers) for STW. It is the combination of wage rigidity and EPL that makes these schemes desirable for employers. Needless to say, a better policy in this context would be to decentralize wage bargaining. 
We consider below the performance in this respect of the Italian and German STW, the two largest schemes being operated in the OECD area and also those for which more information is available. As shown by Table 3 as well as Boxes 1 and 2, the two schemes have markedly different design features. In particular, the German scheme is explicitly designed for temporary shocks, while the Italian system allows for STW in case of structural adjustment (Cassa Integrazione Straordinaria). German firms have to prove that the business situation has deteriorated temporarily, and have to contribute to the costs of each working hour reduction. This creates substantial incentives to adjust employment eventually, since hourly labour costs tend to increase with the utilization of Kurzarbeitergeld. In contrast, the Italian system expanded during the crisis (Cassa Integrazione in deroga) is paid out of General Government revenues; hence it is a sort of wage subsidy to the firm that has no incentives to reduce STW. Unlike in Germany, the Cassa Integrazione in deroga creates also a strong incentive for employers to reduce hours of work all the way down to zero.

Figure 4 displays estimates of the elasticity of take-up rates in manufacturing to changes in the index of industrial production (we focus only on this subset of sectors as we prefer to work at monthly frequencies). Elasticities are allowed to vary over time as they are estimated in a rolling regression over a 4-year (48 observations) period. 95 per cent confidence intervals are also displayed around the point estimates. Asymmetries between Germany and Italy are quite noticeable: in Germany the elasticity is between -.5 and -.7, that is, an increase by one per cent of the index of industrial production is associated with a .5 to .7 reduction in the take-up rate. In Italy instead the responsiveness of STW to the volumes of economic activity is not statistically different from zero except in the most recent periods and, in any event, it does not exceed .3 in modules, that is, it is less than half as sizeable as in Germany.

Figure 4: Elasticity of take-up rates to Economic Activity Rolling Regressions - 48 months

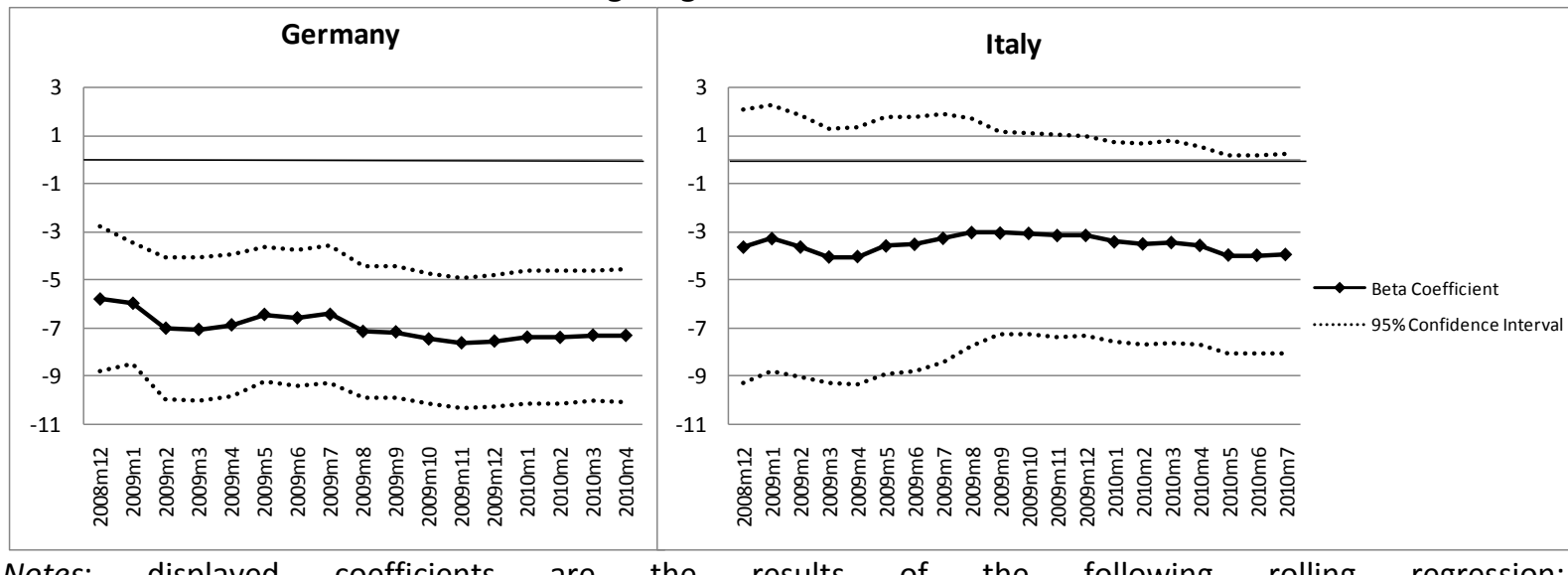

Notes: displayed coefficients are the results of the following rolling regression: $\Delta \log S T W=\alpha+\beta \Delta \log I P I+\varepsilon$, where STW is the number of hours of short-time work programmes in the industrial sector and IPI is the industrial production index

Source: for Italy, INPS (Istituto Nazionale Previdenza Sociale); for Germany, Statistik der BA, Zeitreihen Zeitreihe zu Kurzarbeiter Deutschland 
Table 5 looks at the sectoral and regional concentration of STW before (2007) and during (2009) the Great Recession. In particular it computes a standard measure of concentration, the Herfindahl index, across 19 sectors and the top 30 per cent to bottom 30 per cent ratio across 20 Italian regions and 15 German Länders (we use this measure as it is comparatively more meaningful when the size of regions is different across countries). Problems of crosscountry comparability arise also with respect to the sectoral Herfindahl index as the industry breakdown in take-up rates is somewhat different in Germany and Italy.

With the above caveats in mind, Table 5 suggests that the sectoral concentration, which was relatively strong already in the 2005-7 period, increased by another 20 per cent in Italy throughout the Great Recession. Indeed a few sectors (manufacture of fabricated metal products and textiles) together absorb almost 56 per cent of the total number of hours spent in the STW scheme. Also the geographic concentration increased as the first three deciles of the distribution of the regional population by incidence of the Cassa Integrazione displayed a take-up rate 3 times as large as the bottom four regions of this distribution, compared with 1.5 before the Great Recession.

Table 5: STW Concentration Indexes (full-time equivalents)

\begin{tabular}{ccccc} 
& \multicolumn{2}{c}{ Herfindahl Index (sector) } & \multicolumn{2}{c}{$\begin{array}{c}\text { Regional Concentration } \\
\text { (top-30\% to bottom-30\% ratio) }\end{array}$} \\
\hline \multirow{2}{*}{ Italy } & Q1 2005- Q2 2008 & Q3 2008 - Q2 2009 & 2007 & 2009 \\
\hline \multirow{3}{*}{ Germany } & 0.19 & 0.23 & 1.61 & 3.03 \\
& $(1.18)$ & $(0.74)$ & $(0.49)$ & $(0.30)$ \\
& 0.15 & 0.15 & 1.28 & 1.76 \\
& $(5.24)$ & $(3.82)^{\mathrm{a}}$ & $(0.21)$ & $(0.75)$ \\
\hline
\end{tabular}

Notes: Coefficient of variation of percentage change of valued added by sector in 2007 and 2009 ( 2008 for Germany) and of regional GDP decline in 2007 and 2009 in parentheses.

The Herfindahl index is computed over 19 sectors. Classification is not exactly the same for the two countries, but efforts have been made in order to harmonize data. Both sectoral and regional concentration indexes are computed with respect to total hours spent in STW

Source: for Italy, INPS (Istituto Nazionale Previdenza Sociale); for Germany, Statistik der BA, Zeitreihen Zeitreihe Kurzarbeiter in Deutschland. Regional GDP for Italy, ISTAT, and valued added from Eurostat.

The situation is quite different in Germany as here the sectoral concentration did not change over time, while the regional concentration increased but less than in Italy. Importantly, output falls by region were more concentrated in Germany than in Italy (see the coefficients of variation displayed in brackets in table 5), while in Italy the dispersion of sectoral value added growth actually decreased since the beginning of the Recession.

Overall it would seem that the German Kurzarbeit scheme is better designed than the Italian Cassa Integrazione as it is strongly countercyclical and less concentrated during recessions. Indeed in Germany the take-up rate increased to up to 5.4 per cent in May 2009 and subsequently declined to 2.3 per cent in April 2010 while in Italy it was still on the rise In January 2011, six quarters after the trough of the recession. 


\subsection{Did STW save jobs during the Great Recession?}

A key issue in evaluating STW relates to the number of jobs which were potentially saved by these schemes during the Great Recession. It is clearly very difficult to evaluate the counterfactual, that is, employment adjustment in the absence of STW. This problem is compounded by the fact that STW, as we have seen, is much different from country to country.

We provide below two set of estimates of the jobs saved by STW. The first draws on macro estimates of the responsiveness of employment to changes in STW take-up rates. It has the advantage of capturing general equilibrium effects of STW, but clearly at the costs of accuracy. In particular, due to a paucity of observations, we cannot provide separate estimates for the individual countries and we already know from Section 3 how different short-time work schemes are from country to country. There is also a problem of endogeneity as STW take-up rates are themselves affected by employment-unemployment developments. Unlike previous studies, however, we instrument take-up rates in order to make causal inferences about the relationship between STW and employment.

The second set of estimates is based on micro evidence on establishment-level employment adjustment in Germany, drawing on the IAB establishment panel. This second set of estimates does not take into account the effects of STW on job creation pointed out by the literature, nor of potential fiscal spillovers, but controls for the characteristics of firm using STW. It also uses firm-level instruments to identify causal effects of STW.

\subsubsection{The Macro Approach}

In the macro approach we estimate the following equation in all countries for which we have a quarterly series on employment, value added and STW take-up rates

$$
\mathrm{de}_{\mathrm{it}}=\mathrm{a}_{\mathrm{i}}+\beta * \mathrm{dy}_{\mathrm{it}}+\gamma_{1} * \mathrm{STWR}_{\mathrm{it}}+\gamma_{2} * \mathrm{STWR}_{\mathrm{it}} * d \mathrm{dy}_{\mathrm{it}}+\delta_{\mathrm{it}} \mathrm{EPL}_{\mathrm{it}}+\mathrm{u}_{\mathrm{it}}
$$

where de and $d y$ denote the log difference of employment and output respectively while STWR stands for take-up rates of short-time work (employees at reduced hours over total dependent employment, the longest take-up series available) and EPL is the OECD index of employment protection. The two key coefficients are in this context $\gamma_{1}$ and $\gamma_{2}$. The former measures the contribution of STW to employment variation when there is zero output growth. The second coefficient captures the way in which short-time work affects the elasticity of employment variation to output changes.

Table 6 displays the results of this regression. The first column is estimated via OLS, while the second uses as instruments the time elapsed since the first introduction of a STW scheme in any given country or a subsequent reform of this program (the instruments are the log of the number of quarters since the reform up to the next reform). The identification assumption is that there is a learning process about the new rules which affects take-up rates, but not directly the adjustment of employment to output changes. 
Table 6: Regression Results

\begin{tabular}{|c|c|c|}
\hline & Dep. Variable: De & ent) employment \\
\hline & $(1)$ & (2) \\
\hline & OLS & IV (2sls) \\
\hline GDP Growth & $0.177^{* * *}$ & $0.187 * * *$ \\
\hline & $(0.0304)$ & $(0.0331)$ \\
\hline Employment Protection & 0.778 & 0.635 \\
\hline & $(0.604)$ & $(0.609)$ \\
\hline STW take-up rate & $-0.114^{* *}$ & $-0.194 * *$ \\
\hline & $(0.0595)$ & $(0.0877)$ \\
\hline GDP Growth $x$ STW take-up rate & $-0.051 *$ & $-0.074 *$ \\
\hline & $(0.0305)$ & $(0.0434)$ \\
\hline Constant & -0.602 & -0.402 \\
\hline & (0.889) & $(0.895)$ \\
\hline Country Fixed Effects & Yes & Yes \\
\hline Observations & 557 & 519 \\
\hline R-squared & 0.212 & 0.208 \\
\hline
\end{tabular}

Source: $\mathrm{OECD}$

In both specifications we find that our parameters of interest, $\gamma_{1}$ and $\gamma_{2}$, are negative and statistically significant. The IV estimates are always larger in modules, which is in line with the idea that employment growth negatively affects take-up rates. Both the OLS and the IV estimates imply that STW contributes to reducing dis-employment only in presence of sizeable output falls. In the case of the instrumental variable estimates, the decline of GDP should be larger than 2.6 per cent for STW to prevent job losses. The non-monotonic effects of STW on employment adjustment to output are visually characterized in Figure 5 which also displays 95 per cent confidence bands around our point estimates. We hold take-up rates constant at the cross-country average of 1.23 in our sample. However, we know from Section 3 that STW take up rates are themselves decreasing in output growth. Thus, it is quite unlikely that we could observe the unambiguously positive effect of STW on job losses implied by the diagram during upswings. 
Figure 5

Implied \% of Jobs "saved" by STW depending on output fall

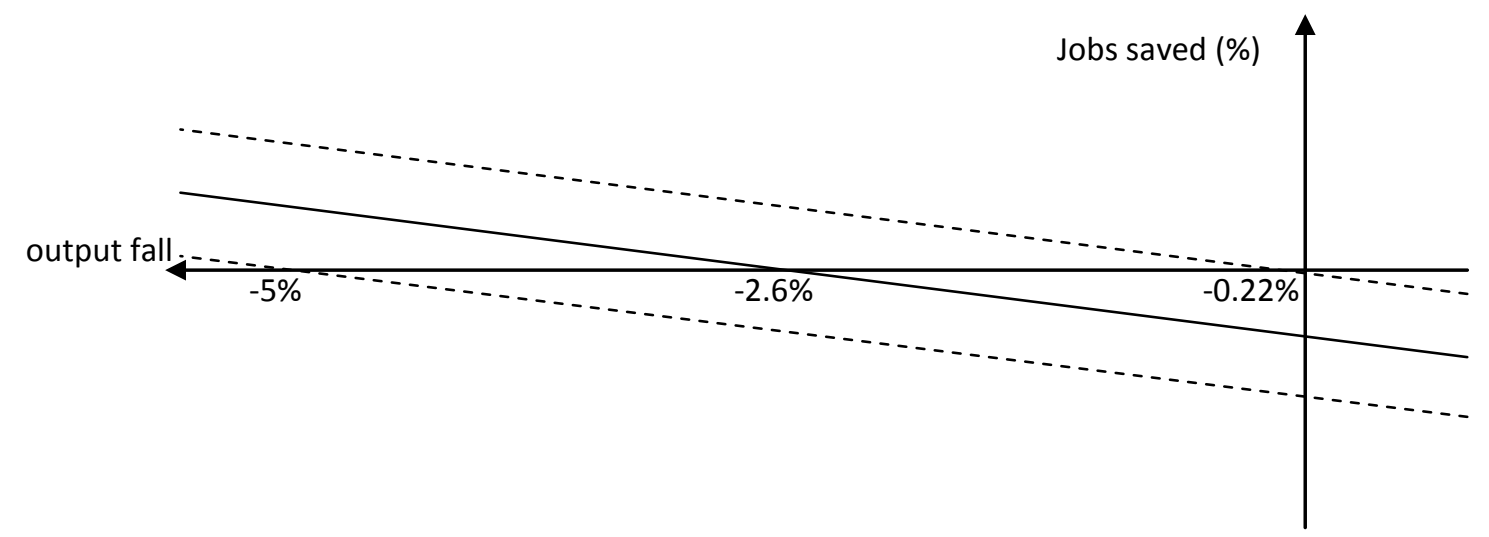

Table 7 provides an estimate of the jobs potentially saved by STW during the Great Recession, by using the IV estimator and taking for each country the average take-up rate and the cumulative, peak-to-trough, GDP decline. Significantly the effect is always positive although in many cases it is almost negligible, and it is always lower than the total number of workers involved in the program, pointing to deadweight costs. Unsurprisingly we find the largest effects in the countries having experienced the deepest output falls, such as Ireland and Finland, in spite of the relatively small scale of the programmes in these countries.

Table 7: Macro Estimates of the Jobs Saved by STW during the Great Recession

\begin{tabular}{l|cc|rr|r|r} 
& $\begin{array}{c}\text { Average } \\
\text { STW take- } \\
\text { up (2008- } \\
\text { 2009) }\end{array}$ & $\begin{array}{c}\text { Cumulative } \\
\text { GDP Decline } \\
\text { (2008-2009) }\end{array}$ & $\begin{array}{r}\text { Jobs Saved as } \\
\text { \% 2008Q4 } \\
\text { Employment } \\
\text { (IV) }\end{array}$ & $\begin{array}{c}\text { Number } \\
\text { of Jobs } \\
\text { Saved } \\
\text { (IV) }\end{array}$ & $\begin{array}{c}\text { STW } \\
\text { partici- } \\
\text { pants }\end{array}$ & $\begin{array}{r}\text { Deadweight } \\
\text { Loss }\end{array}$ \\
\hline Austria & 0.41 & -5.23 & 0.08 & 2,842 & 14,512 & 11.670 \\
Belgium & 4.73 & -4.28 & 0.59 & 22,535 & 179,203 & 156.668 \\
Canada & 0.13 & -3.30 & 0.01 & 1,000 & 28,942 & 27.942 \\
Czech Republic & 1.46 & -4.92 & 0.25 & 10,558 & 60,084 & 49.526 \\
Finland & 1.07 & -10.10 & 0.60 & 13,023 & 22,023 & 9,000 \\
France & 0.49 & -3.93 & 0.05 & 11,067 & 122,167 & 111,067 \\
Germany & 0.77 & -6.76 & 0.24 & 82,725 & 259,645 & 176,920 \\
Hungary & 0.25 & -8.11 & 0.10 & 3,506 & 14,803 & 11,297 \\
Ireland & 0.60 & -15.14 & 0.56 & 9,469 & 9,645 & 176 \\
Italy & 1.58 & -6.95 & 0.51 & 89,416 & 274,239 & 184,823 \\
Japan & 0.04 & -8.93 & 0.02 & 10,011 & 21,182 & 11,171 \\
Luxembourg & 0.37 & -5.31 & 0.07 & 137 & 681 & 544 \\
Netherlands & 0.28 & -5.44 & 0.06 & 4,500 & 37,577 & 33,077 \\
Portugal & 0.02 & -3.89 & 0.00 & 67 & 2,763 & 2696 \\
Spain & 1.02 & -4.98 & 0.18 & 30,400 & 160,572 & 130,172 \\
Switzerland & 0.57 & -3.36 & 0.03 & 1,136 & 22,634 & 21,498
\end{tabular}

Notes: The third columns displays the product $\left(\gamma_{1}+\gamma_{2} * d y_{i t}\right) * S T W R_{i t}$ according to IV estimates, while the fifth multiplies this by the number of employees in 2008Q4, before the beginning of the dis-employment process. The average STW take-up rate is computed only over the recession quarters, i.e. the same period over which we compute cumulative GDP decline. 
Unfortunately, the limited number of observations does not allow us to recover parameter estimates for each individual country. Applying the same coefficient to all countries may bias downward our estimates of the jobs saved for the countries with more efficient STW and upwards those for the countries with rather ineffective schemes in place.

\subsubsection{The Micro Approach}

The evidence provided in the previous sections draws on aggregate figures at the national, regional and sectoral level. In this section we use firm-level data from Germany to gain additional insights as to the effects of STW during the Great Recession. Although Germany is one of the OECD countries which applied STW benefits at a larger scale during the Great Recession, there are also other mechanisms which facilitated the adjustment at the intensive margin. One of these instruments is working-time accounts (WTAs). They are flexible arrangements where employees receive a credit for over-time working hours, which can be used later on to reduce working time or acquire additional holidays. Analogously, if employees work fewer hours than established in the contract, there is a debt which has to be balanced later. Thus, working-time accounts enable firms to smooth the working time over the business-cycle without additional costs which are for example due in case of overtime-work (see Bellmann and Gerner 2010 for details). While the full-time equivalent of STW benefits amounted to 360,000 jobs in Germany in 2009, the reduction on overtime working hours between 2008 and 2009 was equal to 285,000 full-time equivalents and the change in the balance of the working-time accounts amounted to 244,000 full-time equivalents (Möller 2010). Since short-time work benefits and working-time accounts might be substitutes in the adjustment at the intensive margin, we shall consider also the effects of working-time accounts.

Our microeconomic estimates draw on data from the 2009 IAB establishment panel (IAB Betriebspanel) in Germany. The IAB establishment panel is an annual survey of approximately 16,000 firms which covers about 1 per cent of all firms and 7 per cent of the employees in Germany (cf. Fischer et al., 2009, and Kölling, 2000, for a description). The question on the utilisation of STW was asked in the 2003, 2006 and 2009 waves of the survey. ${ }^{5}$ Information on working-time accounts (WTA) is available in the 1999, 2002, 2004, 2006, 2008 and 2009 waves. $^{6}$ Firm information include turnover and profitability in the previous year, revenue expectations in the current year, labour turnover and the skill composition of the workforce as well as institutional features such as the structure of collective bargaining, the presence of worker councils, the use of fixed-term and other temporary contracts and the incidence of temporary agency work.

Previous literature, based on the same database has looked at the question whether the use of Kurzarbeit is associated with an adjustment to economic shocks at the intensive margin. Based on the 2003 wave of the survey, Deeke (2005) provides descriptive evidence that firms which apply short-time work schemes display less employment volatility (measured in

\footnotetext{
${ }^{5}$ The question asked is as follows: "Did you use short-time work during the $1^{\text {st }}$ half year of 2009?" If yes: "How many employees were on short-time work?”

${ }^{6}$ The question asked is as follows: „Are there working-time accounts in your firm/establishment?" If yes: “Please estimate: What is the percentage of employees participating in this scheme?”
} 
terms of labour turnover) than firms which did not use STW. Crimann et al. (2010) find a negative correlation between firms using Kurzarbeit and the utilization of temporary contracts, such as temporary agency work, freelancers and part-time workers. Moreover, Bellmann and Gerner (2010) find ambiguous evidence on the role of STW take-up by comparing firms which use Kurzarbeit and those which do not: on the one hand, firms which use STW have reduced employment significantly in 2009 whether adversely affected by the crisis or not, while firms which do not use STW have reduced their employment only when they suffered from the crisis. The authors conclude that "the identification of a causal effect of (...) short-time work finally, is left for future research." (Bellmann and Gerner, 2010, p. 16). In other countries, Calavrezo et al. (2009) find a positive correlation between layoffs and STW in France, which might be traced back to the fact this study does not sufficiently control for the selection problem. A comprehensive study of the STW programmes in the United States carried out by Berkeley Planning Associates \& Mathematica Policy Research (1997) find no clear-cut evidence. This report concludes that the findings suffer from selection bias such that further empirical work is needed (see also Cahuc and Carcillo, 2011, for a review).

Our approach differs in two main respects from the previous literature. First, we use the panel structure of the dataset to identify whether the STW take-up is driven by variables which capture pre-crisis business conditions and structural problems of firms or by variables which capture current business conditions and expectations about the future. This provides new insights as to the question whether the take-up of STW is used to hinder employment adjustment to structural problems at the firm level predating the crisis. Given that the 2008 wave of the IAB establishment panel took place in June 2008 and the 2009 wave one year later, the pre- and post crisis conditions are fully covered by the dataset. Secondly, we try to identify the impact of STWs and of WTAs on the employment adjustment of firms during the Great Recession using an instrumental variable approach which explicitly acknowledges the endogeneity of STW and of WTAs.

\subsubsection{Descriptive evidence}

Table 8 provides descriptive statistics on the characteristics of firms which use STW and WTAs compared to those which do not for the crisis year 2009. According to the weighted figures of the IAB Establishment Panel, 4.8 per cent of the firms have taken-up STWs by the mid of 2009. On average, about 50 per cent of the workforce participates in firms which utilize STW. In total, 2.1 per cent of the workforce is covered by STW. At the same time, almost one-third of the firms had WTAs in place. Roughly one third of German employees (28 per cent) participated in WTAs in Germany by the mid of 2009.

Firms which took-up STW had substantially more employees than the average firm, had a disproportionally high export share and a high level of research and development activity. The share of part-time workers and female workers of firms which utilized STW has been substantially below that of the average firm. This corresponds to the standard pattern in the manufacturing sector in Germany, which has been mainly affected by the Great Recession and, hence, participated disproportionally in STW. Interestingly enough, the share of fixedterm contracts of firms which took-up STW has been below that of the average firm, while the share of temporary agency workers has been slightly above the average. Among the institutional features, we observe that a disproportionally large share of firms which utlise 
STWs have a worker council in place and a slightly higher share of these firms are led by a porofessional management compared to the sample average.

Most striking is the fact that firms which utilized STW have been disproportionally affected by the Great Recession: almost two-thirds report that they expect a decline in revenues in the year 2009 compared to 28 per cent of the average firm. The average decline in revenues is expected to amount to 19 per cent in firms which took-up STW compared to 3.3 per cent in the average firm. Moreover, firms participating in STW are also disproportionally represented among those which report a turnover decline in 2008, i.e. the year where the Great Recession has started: 40 per cent of the firms using STW report a turnover decline in 2008 compared to 24 per cent in the sample average. Firms which take-up STW report also that they suffer more from competitive pressures.

Interestingly enough, there seems to be no correlation between the take-up of STW and past business results at first glance: The profitability of firms which participate in STW has been similar to the average firm in the pre-crisis year 2007. Another interesting feature is that firms which use STW have reported more than proportionally that they suffered from labour shortages and recruitment problems before the crisis in June 2008. 
Table 8 - Characteristics of firms which take-up STW and use WTA, 2009

\begin{tabular}{|c|c|c|c|}
\hline & \multicolumn{2}{|c|}{ firms which ... } & \multirow{2}{*}{$\frac{\text { all }}{\text { firms }}$} \\
\hline & take-up STW & use WTA & \\
\hline \multicolumn{4}{|l|}{ Expected Revenue Growth 2009} \\
\hline positive (in \%) & 7.8 & 18.9 & 16.7 \\
\hline unchanged (in \%) & 27.6 & 49.5 & 55.0 \\
\hline negative (in \%) & 64.6 & 31.6 & 28.3 \\
\hline average growth in \% & -18.9 & -3.3 & -3.3 \\
\hline High competitve pressure 2009 (yes in \%) & 55.8 & 40.8 & 39.8 \\
\hline Firm survival at risk 2009 (yes in \%) & 0.6 & 0.6 & 0.7 \\
\hline Turnover decline 2008 vs. 2007 (yes in \%) & 40.0 & 23.3 & 24.0 \\
\hline High competitive pressure 2008 (yes in \%) & 52.5 & 42.2 & 38.9 \\
\hline Labour shortages 2008 (yes in \%) & 52.9 & 43.4 & 33.8 \\
\hline \multicolumn{4}{|l|}{ Profitability in 2007} \\
\hline positive (in \%) & 75.0 & 76.9 & 73.2 \\
\hline zero (in \%) & 16.1 & 15.6 & 18.4 \\
\hline negative (in \%) & 8.9 & 7.4 & 8.4 \\
\hline Export share (in \% of turnover) & 10.9 & 4.0 & 3.0 \\
\hline High $R \& D$ activity (yes in \%) & 13.6 & 8.6 & 4.9 \\
\hline High technology standard (yes in \%) & 60.0 & 71.4 & 65.8 \\
\hline \multicolumn{4}{|l|}{ Education: share of workers with } \\
\hline no degree in $\%$ & 22.6 & 19.9 & 20.1 \\
\hline vocational training degree in \% & 57.4 & 58.2 & 51.7 \\
\hline university degree in $\%$ & 5.4 & 8.7 & 6.7 \\
\hline management/owners in \% & 14.6 & 13.2 & 21.6 \\
\hline Part-time workers (in \%) & 12.7 & 24.7 & 27.3 \\
\hline Temporary agency workers (in \%) & 14.6 & 14.6 & 7.2 \\
\hline Fixed-term contract workers (in \%) & 2.3 & 4.2 & 3.0 \\
\hline Female share (in \%) & 24.9 & 44.8 & 47.8 \\
\hline \multicolumn{4}{|l|}{ Firm dependency } \\
\hline independent firm (yes in \%) & 70.6 & 63.8 & 72.7 \\
\hline dependent affiliate (yes in \%) & 18.2 & 22.4 & 17.0 \\
\hline firm headquarter (yes in \%) & 10.4 & 10.6 & 7.9 \\
\hline other (in \%) & 0.8 & 3.2 & 2.4 \\
\hline \multicolumn{4}{|l|}{ Management structure } \\
\hline managed by owner (yes in \%) & 51.5 & 52.1 & 66.3 \\
\hline professional management (yes in \%) & 37.4 & 38.1 & 26.5 \\
\hline joint managment (yes in \%) & 11.1 & 9.8 & 7.2 \\
\hline Collective wage agreement (yes in \%) & 51.5 & 60.7 & 49.1 \\
\hline Worker council (yes in \%) & 45.3 & 47.3 & 31.3 \\
\hline Average number of employees & 49.8 & 33.5 & 17.4 \\
\hline \multicolumn{4}{|l|}{ participation in STW and WTA } \\
\hline share of firms which take-up STW (in \%) & 100.0 & 7.7 & 4.8 \\
\hline share of firms which use WTA (in \%) & 51.8 & 100.0 & 32.1 \\
\hline share of employees on STW (in \%) & 49.4 & 3.4 & 2.1 \\
\hline share of employees on WTA (in \%) & 44.9 & 87.3 & 27.8 \\
\hline
\end{tabular}

Source: Own calculation based on the IAB Establishment Panel. All figures displayed are weighted. 
Firms which utilize WTAs share, by and large, the same characteristics as the average firm. Their expected revenues in $\mathbf{2 0 0 9}$ are slightly above the average and the same is true for their profitability in the pre-crisis year 2007. Export-shares, R\&D activity and the technology level of machinery and other equipment are also slightly above that of the average firm. The most striking differences to the sample average are the relatively high shares of fixed-term contracts and temporary agency workers. This seems to indicate that firms which use working-time accounts also seek flexible arrangements which facilitate the adjustment of employment at the extensive margin. Moreover, a larger share of firms which use WTA have worker councils and collective wage agreements in place than the sample average. Particularly the first finding is not surprising since WTAs are usually based on mutal agreements between worker councils and the firm management.

Finally, there is a correlation between the utilization of WTA and STW take-up rates: Firms which use WTA have a disproportionally high STW take-up rate and a larger share of their workforce participates in STW compared to the average firm.

\subsubsection{The determinants of STW}

In the first stage of our econometric analysis we explain the demand for Kurzarbeit by regressing the STW take-up rate against variables which measure business shocks before the crisis and during the Great Recession, structural characteristics of the firm (export share, R\&D activities, the technological level of machinery and equipment), human capital characteristics of the workforce, the type of labour contracts (temporary agency work, temporary contracts) and institutional variables.

The first column in table 9 presents the results of the regression of the short-time work takeup rate against structural firm characteristics. This indicates that a high level of R\&D activities, a high export share, a large firm size and a high share of workers with a vocational training degree are positively correlated with the STW take-up rate. Moreover, the longer the previous experience of the employer with STW, the higher is the take-up of STW in 2009. ${ }^{7}$

In contrast, firms which employ state-of-the art machinery and technology and firm headquarters participate less in STW schemes. An intriguing finding is that contractual arrangements which facilitate an adjustment at the extensive margin, i.e. the share of temporary agency workers in a firm and the share of workers with a fixed-term contract are negatively correlated with the take-up of short-term benefits. The same holds true for the share of part-time workers. Regarding the skill structure of the workforce, we find that a higher share of workers with a university degree and a higher share of owners and managers in the workforce of a firm are negatively correlated with the STW take-up rate. However, we do not find a significant correlation between STW take-up rate and the way firms are managed (by owners or professional managers), collective wage agreements and some other firm features. The industry-level and regional level controls which are not displayed in table 9 suggest that manufacturing firms use more short-time work benefits and that regions with

\footnotetext{
${ }^{7}$ We have used the information on the take-up of STW in the 2003, 2006 and 2009 waves of the survey for constructing the experience variable. See our discussion of the STW experience variable as an instrument below for further details.
} 
a high concentration of export-oriented firms are over-represented among users of STW schemes.

Table 9 - Determinants of short-time work benefits

\begin{tabular}{|c|c|c|c|c|c|}
\hline & controls only & \multicolumn{2}{|c|}{$\begin{array}{c}\text { pre-crisis variables } \\
\text { and controls }\end{array}$} & \multicolumn{2}{|c|}{$\begin{array}{c}\text { post-crisis variables } \\
\text { and controls }\end{array}$} \\
\hline Revenue growth 09 & & & & $-0.214^{* * *}$ & $(0.011)$ \\
\hline$D E C L I N E$ & & & & $0.023^{* * *}$ & $(0.004)$ \\
\hline RISK & & & & -0.024 & $(0.018)$ \\
\hline COMPET O9 & & & & $0.015^{* * *}$ & $(0.004)$ \\
\hline NEGATIVE RESULT O & & 0.003 & $(0.008)$ & & \\
\hline POSITIVE RESULT 07 & & 0.002 & $(0.005)$ & & \\
\hline COMPET 08 & & $0.012^{* * *}$ & $(0.004)$ & & \\
\hline SHORTAGE 08 & & 0.001 & $(0.004)$ & -0.004 & $(0.004)$ \\
\hline Exportshare & $0.090^{* * *}(0.012)$ & $0.091^{* * *}$ & $(0.012)$ & $0.064^{* * *}$ & $(0.013)$ \\
\hline$H I G H R \& D$ & $0.043^{* * *}(0.007)$ & $0.043^{* * *}$ & $(0.007)$ & $0.039^{* * *}$ & $(0.007)$ \\
\hline HIGH TECH & $-0.027^{* * *}(0.004)$ & $-0.028^{* * *}$ & $(0.004)$ & $-0.021^{* * *}$ & $(0.004)$ \\
\hline EDUCATION 2 & $0.000^{* * *}(0.000)$ & $0.000^{* * *}$ & $(0.000)$ & $0.000^{* * *}$ & $(0.000)$ \\
\hline EDUCATION 3 & $-0.001^{* * *}(0.000)$ & $-0.001^{* * *}$ & $(0.000)$ & $-0.001^{* * *}$ & $(0.000)$ \\
\hline EDUCATION 4 & $-0.001^{* * *}(0.000)$ & $-0.001^{* * *}$ & $(0.000)$ & $-0.001^{* * *}$ & $(0.000)$ \\
\hline Female share & $0.000 \quad(0.000)$ & 0.000 & $(0.000)$ & 0.000 & $(0.000)$ \\
\hline Part-time share & $-0.001^{* * *}(0.000)$ & $-0.001^{* * *}$ & $(0.000)$ & $0.000^{* * *}$ & $(0.000)$ \\
\hline Fixed contract share & $-0.001^{* * *}(0.000)$ & $-0.001^{* * *}$ & $(0.000)$ & $-0.001^{* * *}$ & $(0.000)$ \\
\hline TAW share & $-0.101^{* * *}(0.007)$ & $-0.101^{* * *}$ & $(0.007)$ & $-0.082^{* * *}$ & $(0.007)$ \\
\hline INDEPENDENT & $(0.006)$ & -0.003 & $(0.006)$ & 0.001 & $(0.006)$ \\
\hline HEADQUARTER & $(0.009)$ & -0.015 & $(0.009)$ & -0.014 & $(0.010)$ \\
\hline OWNER & $(0.008)$ & 0.006 & $(0.008)$ & 0.010 & $(0.008)$ \\
\hline MANAGEMENT & $(0.008)$ & -0.014 & $(0.008)$ & -0.010 & $(0.008)$ \\
\hline COLLECTAGR & $-0.010^{* * *}(0.004)$ & $-0.011^{* * *}$ & $(0.004)$ & $-0.010^{* *}$ & $(0.004)$ \\
\hline CHAMBER & $0.000 \quad(0.007)$ & -0.002 & $(0.008)$ & 0.001 & $(0.008)$ \\
\hline COUNCIL & $0.037^{* * *}(0.007)$ & $0.035^{* * *}$ & $(0.007)$ & $0.034^{* * *}$ & $(0.007)$ \\
\hline log empl. 2008 & $0.013^{* * *}(0.006)$ & $0.013^{* *}$ & $(0.006)$ & 0.008 & $(0.006)$ \\
\hline STW experience & $0.006^{* * *}(0.001)$ & $0.006^{* * *}$ & $(0.001)$ & $0.006^{* * *}$ & $(0.001)$ \\
\hline observations & 9217 & 8936 & & 8186 & \\
\hline$R^{2}$ & 0.236 & 0.279 & & 0.275 & \\
\hline
\end{tabular}

Notes: Heteroscedastcity robust standard errors in parentheses. ${ }^{* * *},{ }^{* *},{ }^{*}$ denote the $1 \%-, 5 \%-$, and $10 \%$ significance levels, respectively. Dependent variable is the short-time work participation rate, i.e. the share of short-time workers in the workforce of the respective firm. Each regression includes also firm size, industry and regional dummy variables. A list of the variables and their definitions is presented in Annex Table A5. 
The regression presented in the second column of table 9 considers also indicators for the business conditions in the pre-crisis year 2007. Interestingly enough, we do not find evidence that a positive or negative business result in 2007 is correlated with the take-up of STW in 2009. This is a strong hint that structural problems of firms in the past have not affected the utilization of STW during the Great Recession. However, there is a strong correlation between the competitive pressures a firm faced before the crisis and the take-up of STW in the crisis year. Labour shortages and problems with the recruitment of workers in the past do not affect the STW take-up significantly in 2009. The effects of other firm characteristics on the demand for Kurzarbeit are in the second regression very similar to those in the first one.

Finally, the regression displayed in the third column of table 9 considers beyond the structural firm characteristics also the current business conditions in the year 2009. Since turnover data and other business results for 2009 were not yet available by the mid of the year, we have to focus on expectations about the business results in the ongoing year. The main variable we use is the expected growth rate of revenues, which is the only continuous variable on business expectations for 2009 available in the survey. The results are striking: an increase in the expected revenues by one per cent reduces the STW take-up rate by 0.2 per cent. Similarly, a dummy variable which captures the turnover decline in 2008 turn out to be highly significant. Moreover, strong competitive pressures increase the STW take-up rate significantly.

Overall, our regression results indicate that the STW take-up rates are mainly affected by contemporaneous or anticipated shocks rather than by long-lasting structural problems of the firms. Moreover, the negative coefficients for the temporary agency worker and temporary contract variables suggest that contractual arrangements which facilitate adjustments at the extensive margin reduce the take-up of STWs significantly. This is in line with the macro results displayed in Section 3. Finally, STW seems to cover mainly workers with a vocational training degree. The demand for STW is lower in firms having a larger share of workers with a university degree or other professionals.

\subsubsection{The determinants of WTAs}

Table 10 presents our first-stage regression results on the determinants of working time accounts. The dependent variable is the share of the workforce participating in working time accounts in any firm. Firms which use WTAs have a high share of R\&D actitivities, state-ofthe-art machinery and equipment and a high share of workers with a vocational training degree. Collective wage agreements and worker councils are also positively correlated with WTAs. There exist also a significant correlation between WTAs and the shares of fixed-term contract workers and temporary agency workers suggesting that firms which use WTAs also seek for instruments which enable them an adjustment at the extenbsive margin. Interestingly enough, we find no correlation between working time accounts and the business conditions in 2009, but a positive correlation between firm profitiability and WTAs in the pre-crisis year 2007. Finally, labour shortages and recruitment problems before the crisis turn out to be significant determinant of WTAs. 
Table 10 - Determinants of working-time accounts

\begin{tabular}{|c|c|c|c|c|c|}
\hline \multirow[b]{2}{*}{ Revenue growth 09} & \multirow[t]{2}{*}{ controls only } & \multicolumn{2}{|c|}{$\begin{array}{l}\text { pre-crisis variables } \\
\text { and controls }\end{array}$} & \multicolumn{2}{|c|}{$\begin{array}{c}\text { post-crisis variables } \\
\text { and controls }\end{array}$} \\
\hline & & & & -0.035 & $(0.026)$ \\
\hline DECLINE & & & & -0.009 & $(0.010)$ \\
\hline RISK & & & & 0.002 & $(0.040)$ \\
\hline COMPET O9 & & & & -0.005 & $(0.009)$ \\
\hline NEGATIVE RESULT 07 & & 0.010 & $(0.018)$ & & \\
\hline POSITIVE RESULT O7 & & $0.035^{* * *}$ & $(0.012)$ & & \\
\hline COMPET 08 & & $0.020^{* *}$ & $(0.009)$ & & \\
\hline SHORTAGE 08 & & $0.060^{* * *}$ & $(0.010)$ & $0.054^{* * *}$ & $(0.010)$ \\
\hline Exportshare & $-0.063^{* *}(0.027)$ & $-0.063^{* *}$ & $(0.027)$ & $-0.052^{*}$ & $(0.029)$ \\
\hline$H I G H R \& D$ & $0.056^{* * *}(0.015)$ & $0.056^{* * *}$ & $(0.015)$ & $0.043^{* * *}$ & $(0.016)$ \\
\hline HIGH TECH & $0.027^{* * *}(0.009)$ & $0.024^{* * *}$ & $(0.009)$ & $0.024^{* *}$ & $(0.010)$ \\
\hline EDUCATION 2 & $0.000^{* *}(0.000)$ & $0.001^{* * *}$ & $(0.000)$ & $0.001^{* * *}$ & $(0.000)$ \\
\hline EDUCATION 3 & $0.000 \quad(0.000)$ & 0.000 & $(0.000)$ & 0.000 & $(0.000)$ \\
\hline EDUCATION 4 & $-0.002^{* * *}(0.000)$ & $-0.002^{* * *}$ & $(0.000)$ & $-0.002^{* * *}$ & $(0.000)$ \\
\hline Female share & $-0.001^{* * *}(0.000)$ & $-0.001^{* * *}$ & $(0.000)$ & $-0.001^{* * *}$ & $(0.000)$ \\
\hline Part-time share & $0.000^{* *}(0.000)$ & $-0.001^{* *}$ & $(0.000)$ & $-0.001^{* *}$ & $(0.000)$ \\
\hline Fixed contract share & $0.001^{* *}(0.000)$ & $0.001^{* * *}$ & $(0.000)$ & $0.001^{* *}$ & $(0.000)$ \\
\hline TAW share & $0.041^{* * *}(0.014)$ & $0.039^{* * *}$ & $(0.015)$ & $0.035^{* *}$ & $(0.015)$ \\
\hline INDEPENDENT & $-0.042^{* * *}(0.014)$ & $-0.042^{* * *}$ & $(0.014)$ & $-0.035^{* *}$ & $(0.015)$ \\
\hline HEADQUARTER & $-0.071^{* * *}(0.020)$ & $-0.070^{* * *}$ & $(0.021)$ & $-0.057^{* * *}$ & $(0.022)$ \\
\hline OWNER & $\begin{array}{ll}-0.017 \quad(0.017)\end{array}$ & -0.012 & $(0.018)$ & -0.016 & $(0.019)$ \\
\hline MANAGEMENT & $0.015 \quad(0.018)$ & 0.018 & $(0.018)$ & 0.021 & $(0.019)$ \\
\hline COLLECTAGR & $0.052^{* * *}(0.010)$ & $0.047^{* * *}$ & $(0.010)$ & $0.053^{* * *}$ & $(0.010)$ \\
\hline CHAMBER & $0.025 \quad(0.017)$ & 0.023 & $(0.017)$ & 0.018 & $(0.018)$ \\
\hline COUNCIL & $0.050^{* * *}(0.015)$ & $0.051^{* * *}$ & $(0.015)$ & $0.045^{* * *}$ & $(0.016)$ \\
\hline log empl. 2008 & $0.006 \quad(0.013)$ & 0.001 & $(0.013)$ & -0.004 & $(0.014)$ \\
\hline WTA experience & $0.037^{* * *}(0.001)$ & $0.037^{* * *}$ & $(0.001)$ & $.03781^{* * *}$ & $(0.002)$ \\
\hline observations & 8186 & 8936 & & 8186 & \\
\hline$R^{2}$ & 0.275 & 0.279 & & 0.275 & \\
\hline
\end{tabular}

Notes: Heteroscedastcity robust standard errors in parentheses. ***, **, * denote the 1\%-, 5\%-, and 10\%significance levels, respectively. Dependent variable is the working time account participation rate, i.e. the share of workers which participate in working-time account arrangements in the workforce of the respective firm. Each regression includes also firm size, industry and regional dummy variables. A list of the variables and their definitions is presented in Annex Table A5. 


\subsubsection{How many jobs were „saved“ by STW?}

Identification of the causal effects of STW on employment adjustment requires finding one or more instruments affecting the demand for STW (and WTA) but not employment adjustment. Needless to say, finding proper instruments is not an easy task. We exploit the information on past experience with the utilisation of STW and WTAs in our survey for the construction of such an instrument. Since the Great Recession is by and large uncorrelated to previous business shocks in Germany, we assume that the experience in using STW affects its current take-up rate, but is not correlated with the employment decline in the crisis year 2009. We use the information on STW take-up in the 2003 and 2006 waves of the survey for the construction of this variable. Note that the first-stage regression results indicate that this variable is strongly and significantly correlated with the STW take-up in $2009 .^{8}$

In case of WTAs we proceed in a similar fashion. Although WTA participation rate is an exogenous variable at the time of the Great Recession, firms more vulnerable to cyclical fluctuations (e.g., producing durable goods) may use WTAs more than others. We used therefore the questions on the utilisation of WTAs from the 1999, 2002, 2004, 2006 and 2008 waves of the survey to construct an experience variable. Unsurprisingly, this variable turns out to be highly significant in our first-stage regressions.

\footnotetext{
${ }^{8}$ See the regression on the determinants of STWs in Table 9 and the first-stage regression results in Annex Table A6.
} 
Table 11 - Explaining the employment impact of short-time work benefits and workingtime accounts

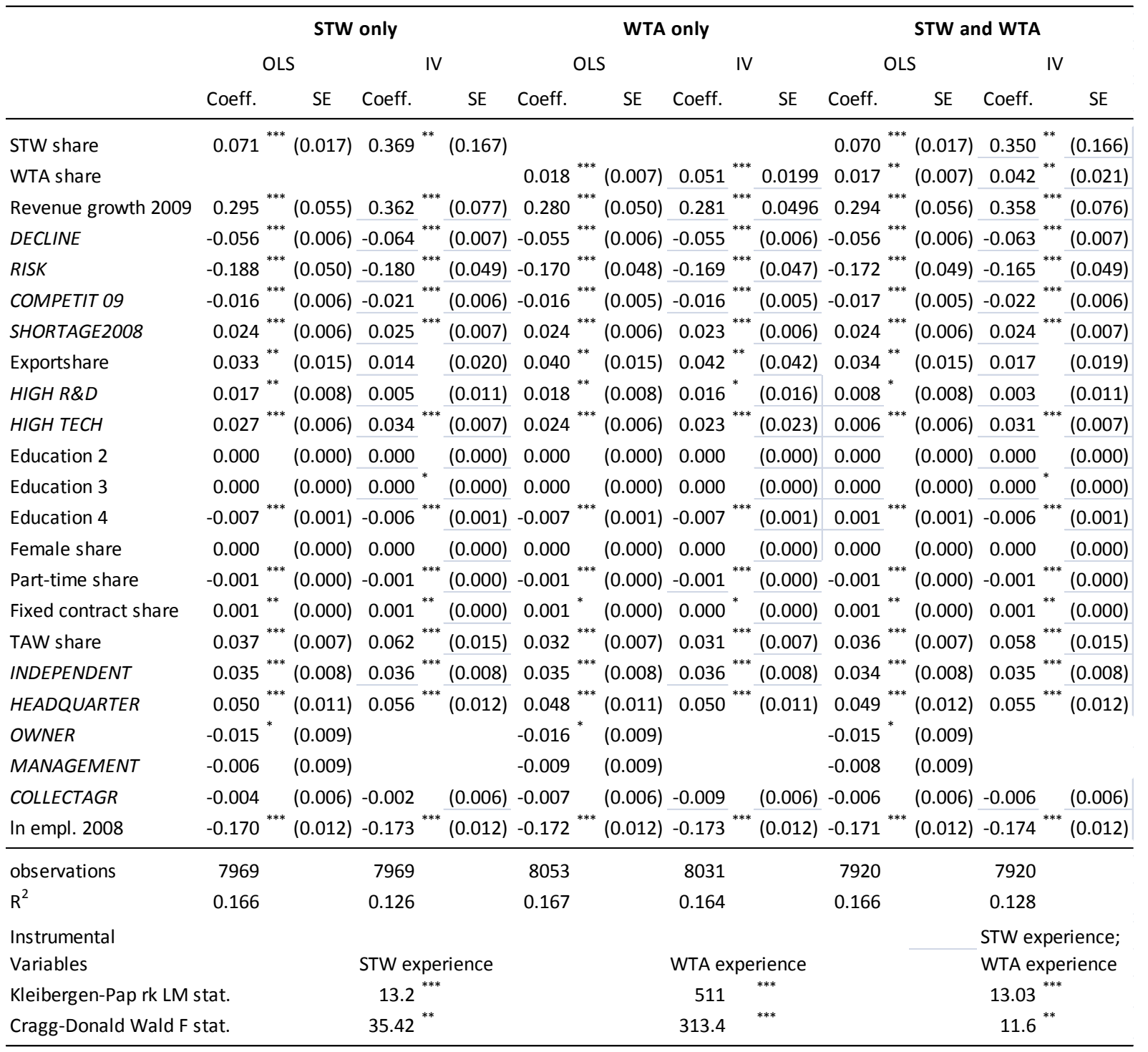

Notes: Heteroscedastcity robust standard errors in parentheses. ***, **, * denote the 1\%-, 5\%-, and 10\%significance levels, respectively. Dependent variable is the log change in the number of workers covered by the social security systems. Each regression includes also firm size, industry and regional dummy variables. A list of the variables and their definitions is presented in Annex Table A5.

Table 11 presents the regression results. We estimated the impact of STW and WTAs first separately and then jointly. To ease the interpretation, we provide both the OLS estimates not controlling for STW endogeneity and regressions where take-up is instrumented based on the first stage estimation. The dependent variable is the change in the logarithm of employment of workers covered by the social security system in June 2009 compared to June $2008 .{ }^{9}$ The main explanatory variable is the number of short-time workers as a share of all employees in the first two regressions displayed in Table 11. The Cragg-Donald Wald Fstatistics and the first-stage regressions presented in Table A6 indicate that our instrument is

\footnotetext{
${ }^{9}$ Note that only to workers covered by the social security system are eligible to receive STW benefits (see Box on Germany for details).
} 
not weak and the Kleibergen-Paap rk LM-statistics rejects the hypothesis of underidentification. ${ }^{10}$

The results from the OLS regression indicate that the STW take-up rate is significant at the one per cent level, although the coefficient is rather small (0.07). In the IV-regression the coefficient increases to 0.37 and remains significant at the 5 per cent level. In other words, increasing the share of short-time workers by one per cent raises employment by about 0.37 per cent. The 95 per cent confidence interval for the parameter is however pretty large: it varies from 0.04 to 0.7 .

The third and the fourth columns in table 11 present our estimates of the effects of WTAs. Again, the regression diagnostics suggests that the IVs are not weak. The coefficient on the participation rate in WTAs is 0.018 in the OLS regression which does not control for potential endogeneity, and 0.051 in the instrumented regression. The latter result suggests that increasing the participation of the workforce in WTAs by one per cent increases employment by 0.051 per cent. The 95 per cent confidence interval of the coefficient varies between 0.01 and 0.09 .

Finally, the fifth and the sixth columns present the results of our regression which include the STW tape-up rate and the WTA participation rate jointly. The regression diagnostics again indicates that our instruments are rather strong. The coefficients on the two main explanatory variables turn out to be significant in both the OLS and the IV regressions and their scale is similar to that in the separate regressions. In the OLS regressions we find a coefficient of 0.07 for the STW-take-up rate and of 0.017 for the WTA participation rate. These coefficients increase in the IV-estimates to 0.35 for STW take-up and to 0.042 for WTA participation.

Given an average full-time equivalent of short-time work of about 40 per cent by the mid of 2009, the point estimate for the STW-take-up rate suggests that the number of jobs saved is at 35 per cent only slightly below the full-time equivalent of STW. For the crisis year 2009, at an average number of 1.147 million short-time workers, our point estimate implies that the STW scheme saved about 400.000 jobs. At the same time it would suggest that there are only small deadweight costs associated to STW, that is, all hours of STW are indeed used to avoid redundancies rather than to finance hour reduction that would have occurred in any event. However, these findings have to be taken with caution, since the IV estimates imply that the 95 per cent confidence interval for the coefficient lies in a range between 0.03 and 0.67. This would correspond to a range between 34.000 and 770.00 jobs which are saved by short-time work benefits.

Analogously, our regression results imply that increasing the participation in WTA by one per cent increases the number of jobs by 0.042 per cent. At a participation rate of 28 of the workforce and 27.5 million workers covered by the social security system in Germany, this would imply that the WTAs would have saved about 320.000 jobs in 2009 . This is slightly

\footnotetext{
${ }^{10}$ We cannot test for overidentification since the equation is exactly identified. As a robustness check, we have used a second instrument (membership in a chamber of commerce of crafts). The Hanson-J-staticts does not reject the Null of no overidentification in this case. However, since our first-stage regression show that chamber membership is weak instrument, we present the exactly identified model here.
} 
higher than the full-time equivalent of the change in the balance of the working-time accounts in Germany in 2009. Needless to say, also these results have to be interpreted cautiously since our parameters are not estimated very precisely and the results of the IVestimates might be biased. The range of the 95 per cent confidence interval is between 62.000 and 616.000 jobs which are saved by WTAs in the course of the Great Recession.

Overall, the microeconomic results are rather encouraging as to the effectiveness of STW and WTAs. However, the results are dependent on the validity of the instruments being used.

\section{$5 \quad$ Summary and Policy Implications}

Short-time work schemes are getting increasingly popular among policy-makers and opinion leaders notably in those countries that so far made little use of STW. This paper aims at providing a balanced view of this set of measures disentangling myths from reality. We offer below an account of our key findings and indicate ways to have a more informed debate about the role of STW.

The rationale for STW is that firms are more likely to adjust the number of workers rather than the working hours in case of temporary shocks to demand. This is inefficient as workers are risk-adverse and there are fiscal externalities associated to layoffs in presence of unemployment benefit systems. This does not necessarily imply that state intervention is needed as these costs could be also internalized if bargaining is decentralized and work sharing agreements exist. However, failures in collective bargaining or liquidity constraints of firms may prevent the provision of flexible worksharing agreements at the decentralized level. Moreover, macro models suggest that STW benefits may serve as a device to prevent wage deflation. However, STW schemes also may involve inefficiencies: employers and employees may collude in extracting state transfers even if firms are no longer facing negative demand shocks. In addition, a prolonged use of STW may prevent to enjoy the productivity gains resulting from workers reallocation from less to more productive jobs. The design features of STW benefit systems are crucial in dealing with these issues.

Our results suggest that STW schemes are highly differentiated across countries along some key dimensions, such as eligibility criteria, entitlement conditions and costs to the employer at different percentages of hours reductions and that these design features matter in affecting take-up rates. Thus, the relevant policy issue is not whether or not to have a STW in place, but which type of STW, if any, should be adopted. After all, most OECD countries already have, by now, some form of STW in place.

We also found that the demand for STW is correlated with the relevance of other institutions dealing with redundancies. In particular, the demand for STW is lower in "flexicurity countries", displaying less strict employment protection and generous unemployment benefits. The low take-up rate of the US STW scheme is also likely to be due to the weak employment protection provided in this country. In order to increase take-up rates significantly in countries with mild employment protection legislation, the state will have to heavily subsidise STW schemes. This circumstance is generally ignored by many debates, notably in the US, about the desirability of enhancing STW. Another key 
institutional feature affecting the demand for STW is the centralization of collective bargaining. In countries with decentralized bargaining structures there is a lower demand for STW perhaps because firm-level agreements can span over hours, employment and wages unlike national agreements that can meaningfully negotiate only over pay.

From a normative standpoint, we find that the presence of job search requirements, the participation of employers in the costs of STW benefits and the fact that the scheme is funded entirely via contributions of employers and employees improve the cyclical properties of STW. In particular, the relatively high involvement of firms in the financing of STW in Germany reduced incentives to use STW to cope with structural problems rather than temporary declines in demand. This is consistent with the steep decline of STW take-up rates in the course of the economic recovery in Germany as well as by our firm level analysis which shows that the pre-crisis business conditions are not correlated with the STW take-up in 2009. Altogether the German Kurzarbeit scheme appears to be superior to the Italian STW scheme (Cassa Integrazione Guadagni) both in reacting to changes in business conditions and in not being concentrated on sectors and firms facing structural redundancies, a polarisation in the use of short-time work which may simply postpone unavoidable job and worker reallocations.

We also evaluate the role played by STW in containing job losses during the Great Recession, the key factor behind the current popularity of STW. The macro estimates point to significant deadweight costs as the number of jobs saved is always smaller than the number of full-time equivalents involved in the schemes. The micro estimates for Germany $(435.000$ jobs saved) are, however, rather encouraging as they point to mild deadweight costs. The partial discrepancy between macro and micro results can be explained by the fact that in the macro estimates we can only partly control for cross-country differences in the design of STW and hence we can only identify the impact of an average STW scheme across the wide spectrum of national schemes. Another possible interpretation for the higher numbers found in the micro estimates is that the latter do not take into account of the general equilibrium effects of STW. As indicated by the body of theoretical literature reviewed in this paper, STW acts also on the job creation margin by reducing hiring rates and this may at least partly offset the effects of STW on employment along the job destruction margin.

Our estimates take policy endogeneity into account, that is, the fact that STW take-up rates increase when business conditions deteriorate. Indeed, estimates controlling for reverse causality imply a higher contribution of STW in containing job losses than estimates not controlling for the effects of employment adjustment on take-up rates.

The econometric results indicate that STW can be effective only in presence of severe recessions. Under milder recessions and during upturns, STW can actually increase employment losses. Thus, it is very important that STW is made responsive to changes in macroeconomic conditions. Experience-rating and co-financing by the employers of a significant share of the costs of the instrument are very important in this respect. Some consideration should also be made to accompanying STW with policies easing the hiring margin. Wage insurance scheme allowing workers moving across firms as well as from STW to new jobs to be compensated for the wage losses initially experienced in this job-to-job shift could be useful to reduce these effects of STW on the hiring margin. 
Another crucial policy issue relates to the financing of STW. We have argued above that STW works better when employers internalize the costs of these schemes. At the same time, high costs for employers reduce take-up rates and may end-up increasing the tax burden on firms just at a time where they need to be encouraged to hire more. One possible way out of this problem is to let average contribution rates to increase during upturns allowing to accumulate a surplus of the fund which could then be used to finance a reduction in contribution rates during downturns.

A final relevant policy issue concerns the coverage by STW of temporary work. Some Governments reacted to the crisis by formally extending the coverage of STW to fixed-term contract holders. While this reform remedies to one of the most long-lasting discrimination in the legal treatment of temporary and permanent workers, the extension did not prove particularly successful. The issue is that STW are only marginally used to provide incomes to temporary workers during downturns and there is no evidence, even when drawing on micro data, that STW reduced job losses among temporary workers. The institutional interactions highlighted in our paper suggest that the negative correlation between STW take-up and the share of fixed-term contracts is likely to be due to the low employment protection provided to these workers. Employers have just no incentives to use STW for them when they know that these workers can be fired at will at the expiration of their contract. The problems of the dualism between temporary and permanent contracts have to be addressed by other reforms, such as the graded employment security scheme presented in previous issues of Economic Policy. 


\section{ANNEX 1: The bias toward workers of employment adjustment}

Consider that the supply of hours of work is given by $h(w)$ where $h^{\prime}>0$ over the relevant wage. Cost minimization of (2) subject to (3) involves that

$$
\min _{n, h} \Lambda=n(F+w(h) h)+y\left(\bar{y}-n^{\alpha} h^{\beta}\right)
$$

where first order conditions are:

i. $\quad F+w(h) h=\alpha y n^{\alpha-1} h^{\beta}$

ii. $\quad n w\left(1+\varepsilon_{n}^{w}\right)=\beta y h^{\beta-1}$

iii. $\quad \bar{y}=n^{\alpha} h^{\beta}$

and $\varepsilon_{n}^{w}=\frac{d w}{d h} \frac{h}{w}$ is the elasticity of the wage function with respect to hours of work. Taking the ratio between $\mathrm{i}$. and ii. and solving for $\mathrm{h}$, we obtain

$$
h=\frac{\beta}{\alpha} \frac{F}{\varepsilon_{n}^{w}}
$$

Substituting this into the condition iii., we obtain an expression for the (conditional) demand of workers

$$
n=\bar{y}^{\frac{1}{\alpha}}\left(\frac{\beta}{\alpha} \frac{F}{\varepsilon_{n}^{w}}\right)^{\frac{-1}{\alpha}}
$$

It follows that

$$
\begin{gathered}
\frac{d h}{d \bar{y}}=0 \\
\frac{d n}{d \bar{y}}=\frac{1}{\alpha} \bar{y} \frac{1-\alpha}{\alpha}\left(\frac{\beta}{\alpha} \frac{F}{\varepsilon_{n}^{w}}\right)^{\frac{-1}{\alpha}}
\end{gathered}
$$

that is, the demand for hours is independent of the scale of production, while the demand for workers is dependent.

Notice further that the responsiveness of the demand of workers to output change is increasing in the elasticity of output to workers $(\alpha)$ and decreasing in fixed costs (F), while it is increasing in the elasticity of the wage function with respect to hours of work. See on this Garibaldi (2006). 


\section{ANNEX 2}

Table A1: STW reforms during the Great Recession

\begin{tabular}{|c|c|c|c|}
\hline Country & $\begin{array}{l}\text { Date of } \\
\text { approval }\end{array}$ & $\begin{array}{c}\text { Date of } \\
\text { implementation }\end{array}$ & Description \\
\hline \multirow[t]{2}{*}{ Austria } & March 2009 & $\begin{array}{l}\text { Backdated to } \\
\text { February } 2009\end{array}$ & $\begin{array}{l}\text { Duration extended (from } 3 \text { to } 6 \text { months) } \\
\text { Combined with specific training grants }\end{array}$ \\
\hline & June 2009 & September 2009 & $\begin{array}{l}\text { Duration extended to } 24 \text { months (up to the end of 2012) } \\
\text { SSC refunded by PES from the 7th months onwards }\end{array}$ \\
\hline \multirow{3}{*}{ Belgium } & \multirow[t]{2}{*}{$\begin{array}{l}\text { October } \\
2008\end{array}$} & \multirow[t]{2}{*}{ Until 2010} & $\begin{array}{l}\text { Temporay increase of compensation. Permanent extension } \\
\text { to temporary agency workers and workers with fixed-term } \\
\text { contracts who worked more than } 3 \text { months in the } \\
\text { enterprise }\end{array}$ \\
\hline & & & $\begin{array}{l}\text { Benefit of blue collar increase up to } 70 \% \text { of reference wage } \\
\text { for a cohabiting employee and } 75 \% \text { for persons living alone }\end{array}$ \\
\hline & April 2009 & & $\begin{array}{l}\text { Additional measure for reduction working-time, whereby } \\
\text { the employment contract of white-collar workers can be } \\
\text { partially or fully suspended, for a maximum duration of } 26 \\
\text { or } 16 \text { weeks }\end{array}$ \\
\hline Canada & \multicolumn{2}{|l|}{ March 2009} & $\begin{array}{l}\text { Duration extended by } 14 \text { weeks and access to the work- } \\
\text { sharing programme is facilited. Paper burden for } \\
\text { employers is reduced }\end{array}$ \\
\hline \multirow{2}{*}{$\begin{array}{l}\text { Czech } \\
\text { Republic }\end{array}$} & \multirow{2}{*}{$\begin{array}{l}\text { February } \\
2009\end{array}$} & \multirow[t]{2}{*}{ March 2009} & $\begin{array}{l}\text { Wage supplement for employees whose working hours } \\
\text { have been reduced }\end{array}$ \\
\hline & & & Conditional to participation in training programmes \\
\hline Denmark & March 2009 & & More flexible access to work-sharing \\
\hline \multirow[t]{3}{*}{ Finland } & $\begin{array}{l}\text { Beginning of } \\
2010 \\
\end{array}$ & & $\begin{array}{l}\text { Wage supplement for employees whose working hours } \\
\text { have been reduced (effective until January 2011) }\end{array}$ \\
\hline & 15 & & \\
\hline & $\begin{array}{l}\text { December } \\
2008\end{array}$ & 1 January 2009 & Increase in benefits and duration \\
\hline \multirow[t]{2}{*}{ France } & $\begin{array}{l}30 \text { March } \\
2009\end{array}$ & & $\begin{array}{l}\text { Extension to all employees (including temporary and part } \\
\text { time workers) }\end{array}$ \\
\hline & $\begin{array}{l}15 \text { April } \\
2009\end{array}$ & May 2009 & Increase in benefits \\
\hline
\end{tabular}




\begin{tabular}{|c|c|c|c|}
\hline \multirow{4}{*}{ Germany } & $\begin{array}{c}\text { Autumn } \\
2008\end{array}$ & & Extended period of eligibility (12 to 18 months) \\
\hline & & & Extended period of eligibility (18 to 24 months) \\
\hline & May 2009 & 1 July 2009 & SSC reimbursed to employers by the local employment agencies \\
\hline & & & Simplified application procedure and less stringent conditions \\
\hline \multirow[t]{2}{*}{ Hungary } & & \multirow[t]{2}{*}{$\begin{array}{c}\text { Implemented } \\
\text { until half } 2010 .\end{array}$} & $\begin{array}{l}\text { Employers are reimbursed social security contributions and up } \\
\text { to two times the minimum wage for hours not worked for a } \\
\text { specified period up to } 12 \text { months in all schemes. }\end{array}$ \\
\hline & & & Training costs (if applicable) are also supported. \\
\hline
\end{tabular}

\begin{tabular}{|c|c|c|}
\hline \multirow{3}{*}{ Japan } & \multirow{3}{*}{ April 2009} & $\begin{array}{l}\text { Eligibility extended to all workers covered by insurance } \\
\text { regardless of the length of coverage }\end{array}$ \\
\hline & & Maximum duration extended from 150 to 300 days \\
\hline & & $\begin{array}{l}\text { For large corporations, subsidy raised from } 67 \% \text { to } 75 \% \text {, while } \\
\text { for SMEs, improved from } 80 \% \text { to } 90 \%\end{array}$ \\
\hline Italy & $\begin{array}{l}\text { December } \\
2008\end{array}$ & $\begin{array}{l}\text { Coverage of the programme temporarily extended to small and } \\
\text { medium-sized firms in the tertiary sector, including retail } \\
\text { companies with more than } 50 \text { employees, tourist agencies and } \\
\text { operators with more than } 50 \text { employees and security companies } \\
\text { with more than } 15 \text { employees. }\end{array}$ \\
\hline \multirow{2}{*}{ Latvia } & \multirow{2}{*}{$\begin{array}{l}\text { September } \\
2009\end{array}$} & $\begin{array}{l}\text { Training to employees whose working hours have been reduced } \\
\text { to at least } 20 \text { hours per week }\end{array}$ \\
\hline & & $\begin{array}{l}\text { Employee receives a scholarship of } 70 \text { LVL per month. Training } \\
\text { courses last a maximum of } 6 \text { months. }\end{array}$ \\
\hline \multirow[t]{2}{*}{ Lithuania } & \multirow[t]{2}{*}{ April 2009} & $\begin{array}{l}\text { Possibility to combine STW and public works. Local PES can pay } \\
\text { up to } 100 \% \text { of remuneration for public works (based on the } \\
\text { minimum hourly wage) and reimburse the associated SSC }\end{array}$ \\
\hline & & $\begin{array}{l}\text { Training grant amounting to up to } 70 \% \text { of the minimum monthly } \\
\text { wage is available }\end{array}$ \\
\hline
\end{tabular}


30 November

2008 until 21

March 2009

Netherlands

1

April Until April 2010

2009

July

2009

Temporary reduced working time scheme. Initially lasting for 6 weeks, it could be extended 3 times for up to 24 weeks. For any hours lost, employees received $75 \%$ of their last earned wage during the first 2 months of the scheme and $70 \%$ of their last wage for any hours lost thereafter.

Eligible companies must meet a number of requirements (fall in sales of $30 \%$ over two months, training obligations, employment contracts not to be terminated until at least 4 weeks after the completion of reduced working hours.

Introduction of Partial Unemployment Benefits replacing the previous scheme. It enables employers to reduce the working hours of employees by a maximum of $50 \%$. The initial request for partial unemployment benefits can cover a period of 13 consecutive weeks (or 3 months). An extension can be applied twice and two extra periods of 26 weeks ( 6 months) of benefits can be granted. As a result, partial unemployment benefits can be used for a maximum of 65 weeks.

Each company can participate to this scheme, given a number of obligations (agreement with trade union representatives; training agreements; penalties in case of dismissals within 3 months from receiving the benefits)

More restricted version of Partial UB. Eligible if working time is reduced by a minimum of $20 \%$ for at least 6 months. Moreover, the more employees are taking part in the STW scheme, the shorter the time period the employee is able to take part in the scheme.

\begin{tabular}{|c|c|c|c|}
\hline Poland & $\begin{array}{l}1 \text { July } \\
2009\end{array}$ & August 2009 & $\begin{array}{l}\text { Working time of employees may be reduced by up to } 50 \% \text { of } \\
\text { normal working time for a period of up to } 6 \text { months. Employers can } \\
\text { then apply for temporary state assistance coving part of the } \\
\text { employees' remuneration. } \\
\text { Employers can also implement a temporary shut-down for a } \\
\text { maximum of } 6 \text { months. Employees receive a benefit equivalent to } \\
\text { the minimum wage. }\end{array}$ \\
\hline Portugal & & $2009-2010$ & $\begin{array}{l}\text { A short-time work scheme already exists (since 1983). Training } \\
\text { opportunities for up to six months during periods of temporary } \\
\text { reduction in normal work or a suspension of employment } \\
\text { contracts. The financial support corresponds to } 85 \% \text { of the wage } \\
\text { compensation payment as set out in the Labour Code. Incentives } \\
\text { for a qualification, up to maximum } 1 / 3 \text { of the normal gross } \\
\text { compensation of the worker. The financial support applies to } \\
\text { maximum } 20 \% \text { of the workers of the enterprise. }\end{array}$ \\
\hline Romania & & $\begin{array}{l}\text { Second quarter } \\
\text { of } 2009 . \text { Then } \\
\text { prolonged until } \\
\quad \text { end } 2010 .\end{array}$ & $\begin{array}{l}\text { Working hours reduction schemes already exist in case of } \\
\text { temporary break of activity (so-called "technical unemployment"). } \\
\text { Introduction of an exemption for a period of up to three months of } \\
\text { the payment of SSC payable by both employers and employees } \\
\text { during temporary interruption of the activity. }\end{array}$ \\
\hline
\end{tabular}


Temporary measure called "Contribution to support maintenance of employment". Following approval of the Labour Office, employers

March 2009 until that reduce normal weekly working hours of their employees and

December 2010 continue to pay compensations at above $60 \%$ of the original wage, receive financial support corresponding to SSC paid by the employer and the employee for hours not worked up to $339 € /$ month for maximum 60 days in the calendar year.

Slovakia Introduction of "flexi-account". For serious operational reasons, the employer, upon agreement with the trade union organisation, may

1 March 2009 until 30 give the employee time off for which the employee is entitled to a

December 201 wage at an amount of at least the basic wage. Once the obstructions to work cease on the part of the employer, the employee is obliged to work extra hours for the time off that was provided without claiming the wage as that had been provided when he was off work.

Subsidy scheme for reduced working hours. The scheme is available to employers who reduce working time of their employees from 40 hours per week to 32-36 hours under certain conditions (no redundancies due to business reasons, continue to pay salaries and SSC, no overtime work and no management bonuses). The subsidy is paid for a maximum of 6 months, with the possibility of prolonging it, upon formal request, for up to further 6 months.

The

Slovenia measure expires in March 2010
Subsidy scheme (complementing the previous one) for employees on temporarily forced leave. Employers temporarily not able to provide work to up to $50 \%$ of their employees are entitled to the scheme (under the same conditions of the previous scheme). At least $20 \%$ of lost working time should be devoted to training. Employees may receive wage compensation up to $85 \%$ of their base wage. The company is refunded $50 \%$ of the affected employee's base wage up to a maximum of $805 €$. The subsidy can be paid for a maximum of 6 months, but can be prolonged by additional 6 months.

\begin{tabular}{|c|c|c|c|}
\hline Spain & $\begin{array}{c}6 \text { March } \\
2009\end{array}$ & $\begin{array}{c}\text { Until } \\
\text { December } \\
2010\end{array}$ & $\begin{array}{l}\text { Changes in collective dismissal procedures in order to facilitate } \\
\text { temporary suspensions instead of definitive layoffs. A worker } \\
\text { affected by a temporary suspension will not suffer from any loss in } \\
\text { unemployment benefits rights. Also, } 50 \% \text { bonus has been decided } \\
\text { in the social security payments in case of temporary suspension } \\
\text { (under some conditions). }\end{array}$ \\
\hline
\end{tabular}

Sources: Own elaboration on Arpaia et al. (2010) and ILO (G20 country brief reports, 2010) 
Table A2: STW - Eligibility and Entitlement Conditions for STW schemes

\begin{tabular}{|c|c|c|c|c|c|c|}
\hline \multicolumn{3}{|c|}{ Eligibility Conditions } & \multicolumn{4}{|c|}{ Entitlement Conditions } \\
\hline Country & $\begin{array}{l}\text { Justification } \\
\text { of economic } \\
\text { need }\end{array}$ & $\begin{array}{l}\text { Social Partner } \\
\text { Agreement }\end{array}$ & $\begin{array}{l}\text { Compulsory } \\
\text { Training }\end{array}$ & $\begin{array}{c}\text { No } \\
\text { Dismissal }\end{array}$ & $\begin{array}{l}\text { Job Search } \\
\text { Requirement } \\
\text { for Employee }\end{array}$ & $\begin{array}{c}\text { Recovery } \\
\text { Plan }\end{array}$ \\
\hline Austria & Yes & Yes & No & Yes & No & No \\
\hline Belgium & Yes & $\begin{array}{c}\text { BC: No } \\
\text { WC: Yes (or } \\
\text { business plan) }\end{array}$ & No & No & No & $\begin{array}{l}\text { BC: No } \\
\text { WC: Yes }\end{array}$ \\
\hline Canada & Yes & Yes & No & No & No & No \\
\hline $\begin{array}{l}\text { Czech } \\
\text { Republic }\end{array}$ & Yes & Yes & Yes & No & No & No \\
\hline Denmark & No & Yes & No & No & Yes & No \\
\hline Finland & Yes & Consultation & No & No & Yes & No \\
\hline France & Yes & Yes & No & Yes & No & No \\
\hline Germany & Yes & Yes & No & No & Yes & No \\
\hline Hungary & Yes & No & Yes & Yes & No & No \\
\hline Ireland & No & No & No & No & Yes & No \\
\hline Italy & Yes & $\begin{array}{c}\text { CIGO: No; } \\
\text { CIGS: } \\
\text { Consultation }\end{array}$ & No & No & No & Yes \\
\hline Japan & Yes & Yes & No & No & No & No \\
\hline Luxembourg & Yes & Yes & No & No & & Yes \\
\hline Netherlands & No & Yes & Yes & Yes & No & No \\
\hline Norway & Yes & No & No & No & Yes & No \\
\hline Poland & Yes & Yes & No & Yes & No & Yes \\
\hline Portugal & & & Yes & No & & No \\
\hline $\begin{array}{l}\text { Slovak } \\
\text { Republic }\end{array}$ & Yes & Yes & No & No & No & No \\
\hline Spain & Yes & No & No & No & Yes & Yes \\
\hline Switzerland & Yes & $\begin{array}{l}\text { Individual } \\
\text { Agreement }\end{array}$ & No & No & No & No \\
\hline
\end{tabular}

Note: Justification of Economic Need = firms must provide a proof, such as a minimum reduction in production and/or business activity; Social Partner Agreement $=$ an explicit agreement between the social partner is required; No Dismissal = prohibition of dismissal during participation in STW schemes; Compulsory Training = workers have to participate in special training programmes; Recovery Plan = firms must develop recovery plan; Job Search Requirement $=$ workers are required to search for a job while participating to STW schemes.

BC: blue collar; WC: white collar; CIGO: Cassa Integrazione Guadagni Ordinaria; CIGS: Cassa Integrazione Guadagni Straordinaria

Source: Alexander Hijzen and Danielle Venn, 2010 (information provided by delegates to the OECD Working Party on Employment). 
Table A3: STW - Further Design Features

\begin{tabular}{|c|c|c|c|c|c|}
\hline Country & $\begin{array}{c}\text { Average } \\
\text { Cost to Employer } \\
\text { in first month }\end{array}$ & $\begin{array}{l}\text { STW net } \\
\text { replacement } \\
\text { rate }\end{array}$ & $\begin{array}{l}\text { Minimum } \\
\text { Permissible } \\
\text { Hours } \\
\text { Reduction }\end{array}$ & $\begin{array}{l}\text { Maximum } \\
\text { Permissible } \\
\text { Hours } \\
\text { Reduction }\end{array}$ & $\begin{array}{c}\text { Maximum } \\
\text { Duration }\end{array}$ \\
\hline Austria & $16.75 \%$ & $47.8 \%$ & $10 \%$ & $90 \%$ & 24 \\
\hline Belgium & $0.00 \%$ & $49.6 \%$ & $0 \%$ & $100 \%$ & 4.5 \\
\hline Canada & $0.00 \%$ & $46.1 \%$ & $20 \%$ & $60 \%$ & 12 \\
\hline $\begin{array}{l}\text { Czech } \\
\text { Republic }\end{array}$ & $25.37 \%$ & $49.5 \%$ & $0 \%$ & $100 \%$ & 6 \\
\hline Denmark & $0.00 \%$ & $42.2 \%$ & $40 \%$ & $100 \%$ & 6 \\
\hline France & $38.84 \%$ & $49.7 \%$ & $0 \%$ & $100 \%$ & 13 \\
\hline Germany & $8.15 \%$ & $48.0 \%$ & $10 \%$ & $100 \%$ & 24 \\
\hline Hungary & $0.00 \%$ & $49.5 \%$ & $20 \%$ & $100 \%$ & 12 \\
\hline Ireland & $0.00 \%$ & $36.2 \%$ & $40 \%$ & $100 \%$ & \\
\hline Italy & $17.00 \%$ & $49.8 \%$ & $0 \%$ & $100 \%$ & 17 \\
\hline Japan & $30.62 \%$ & $49.6 \%$ & $0 \%$ & $100 \%$ & 28 \\
\hline Luxembourg & $8.28 \%$ & $49.8 \%$ & $0 \%$ & $50 \%$ & 6 \\
\hline Netherlands & $0.00 \%$ & $47.3 \%$ & $0 \%$ & $50 \%$ & 13 \\
\hline Norway & $23.08 \%$ & $42.8 \%$ & $40 \%$ & $100 \%$ & 12 \\
\hline Poland & $12.90 \%$ & $49.4 \%$ & $0 \%$ & $100 \%$ & 6 \\
\hline Portugal & $16.00 \%$ & $49.7 \%$ & $0 \%$ & $100 \%$ & 18 \\
\hline $\begin{array}{l}\text { Slovak } \\
\text { Republic }\end{array}$ & $47.54 \%$ & $49.5 \%$ & $4 \%$ & $100 \%$ & 3 \\
\hline Spain & $0.00 \%$ & $43.6 \%$ & $33 \%$ & $100 \%$ & 24 \\
\hline Switzerland & $4.62 \%$ & $49.00 \%$ & $10 \%$ & $100 \%$ & 24 \\
\hline
\end{tabular}

Notes: Cost to Employer $=$ percentage of normal total labour cost for a single worker without children who usually earns the average wage; Average Replacement Rate = benefit from STW schemes as percentage of last wage (average between $\min$ and $\max$ replacement rate); Permissible Hours Reduction = minimum and maximum permissible reductions in weekly working hours for short-time workers during the 2008-2009 recession (a minimum requirement of 1 hour is treated here as $0 \%$ ); maximum duration = maximum duration of STW schemes in months. The information refers to the year 2009.

Source: Alexander Hijzen and Danielle Venn, forthcoming 2011 (information provided by delegates to the OECD Working Party on Employment) 
Table A4: Regression results - STW institutional determinants

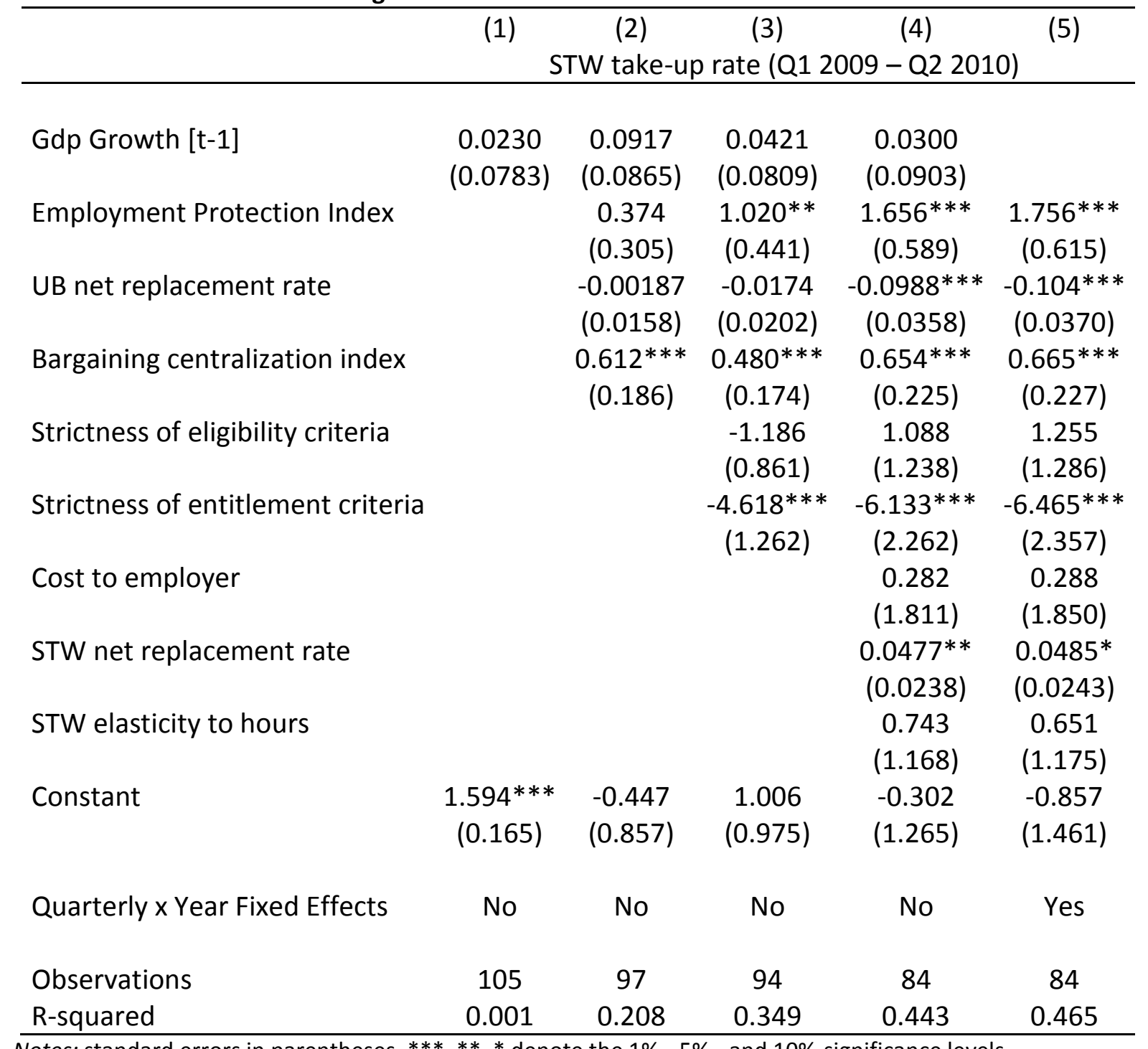

Notes: standard errors in parentheses. ${ }^{* * *},{ }^{* *},{ }^{*}$ denote the $1 \%-, 5 \%-$, and $10 \%$-significance levels, respectively. 
Table A5: List of variables

\begin{tabular}{|c|c|}
\hline STW share & short-time work take-up rate \\
\hline WTA share & working-time account participation rate \\
\hline Revenue growth 09 & expected growth rate of revenues in 2009 \\
\hline DECLINE & turnover decline in 2008 vs. 2007 ( 1 = yes) \\
\hline RISK & Risk of firm closuren or part of firm closure $(1=$ yes $)$ \\
\hline COMPETIT O9 & high competitive pressure 2009 ( 1 = yes) \\
\hline COMPETIT 08 & high competitive pressure 2008 ( 1 = yes) \\
\hline SHORTAGE 08 & labour shortages in 2008 ( 1 = yes $)$ \\
\hline Export share & ratio of exports in turnover \\
\hline$H I G H R \& D$ & high share of R\&D activities ( $1=$ yes) \\
\hline HIGH TECH & state of the art machinery and equipment $(1=$ yes $)$ \\
\hline EDUCATION 2 & share of workers with vocational training in \% of workforce (reference category: unskilled workers) \\
\hline EDUCATION 3 & share of workers with university degree in \% of workforce (reference category: unskilled workers) \\
\hline EDUCATION 4 & share of management and firm owners in \% of workforce (reference category: unskilled workers) \\
\hline Female share & share of female workers in $\%$ of total workforce. \\
\hline Part-time share & share of part-time workers in $\%$ of total workforce. \\
\hline Fixed-term contract sh. & share of workers with fixed contracts in \% of total workforce. \\
\hline TAW share & share of temporary agency workers in \% of workforce. \\
\hline INDEPENDENT & independent firm ( 1 = yes); reference category: dependent firm. \\
\hline HEADQUARTER & firm headquarter ( 1 = yes); reference category: dependent firm. \\
\hline OWNER & firn managed by owner $(1=$ yes $)$; reference category: joint management. \\
\hline MANAGEMENT & firn managed by paid managers $(1=$ yes $)$; reference category: joint management. \\
\hline COLLECTAGR & collective wage agreement ( 1 = yes). \\
\hline COUNCIL & workers council $(1=$ yes $)$ \\
\hline CHAMBER & chamber membership $(1=$ yes $)$ \\
\hline In empl. 2008 & log number of employees subject to social-security contributions in 2008. \\
\hline STW experience & years since first use of short-time work \\
\hline WTA experience & years since first use of working time accounts \\
\hline
\end{tabular}


Table A6: First-stage regression results

\begin{tabular}{|c|c|c|c|c|c|c|c|c|}
\hline \multirow{3}{*}{$\begin{array}{l}\text { dependent variable } \\
\text { Revenue growth } 09\end{array}$} & \multicolumn{4}{|c|}{ Separate Regressions } & \multicolumn{4}{|c|}{ Joint Regression } \\
\hline & \multicolumn{2}{|c|}{ STW } & \multicolumn{2}{|c|}{ WTA } & \multicolumn{2}{|c|}{ STW } & \multicolumn{2}{|c|}{ WTA } \\
\hline & $-0.22^{* * *}$ & $(0.040)$ & -0.037 & $(0.026)$ & $-0.220^{* * *}$ & $(0.040)$ & -0.042 & $(0.027)$ \\
\hline DECLINE & $0.024^{* * *}$ & $(0.005)$ & -0.008 & $(0.010)$ & $0.024^{* * *}$ & $(0.005)$ & -0.009 & $(0.010)$ \\
\hline CLOSURE O9 & $-0.03^{*}$ & $(0.015)$ & -0.004 & (0.039) & -0.025 & $(0.016)$ & -0.003 & (0.039) \\
\hline COMPETIT O9 & $0.015^{* * *}$ & $(0.004)$ & -0.007 & (0.009) & $0.015^{* * *}$ & $(0.004)$ & -0.006 & $(0.009)$ \\
\hline SHORTAGE 08 & -0 & $(0.005)$ & $0.053^{* * *}$ & (0.011) & -0.005 & $(0.005)$ & $0.053^{* * *}$ & $(0.011)$ \\
\hline Export share & $0.062^{* * *}$ & $(0.018)$ & $-0.049^{*}$ & (0.029) & $0.060^{* * *}$ & $(0.018)$ & $-0.045^{*}$ & $(0.029)$ \\
\hline$H I G H R \& D$ & $0.04^{* * *}$ & $(0.009)$ & $0.044^{* * *}$ & $(0.016)$ & $0.040^{* * *}$ & $(0.009)$ & $0.041^{* * *}$ & $(0.016)$ \\
\hline HIGH TECH & $-0.02^{* * *}$ & $(0.005)$ & $0.024^{* * *}$ & $(0.010)$ & $-0.022^{* * *}$ & $(0.005)$ & $0.023^{* *}$ & $(0.010)$ \\
\hline EDUCATION 2 & $-0^{* * *}$ & $(0.000)$ & $0.001^{* * *}$ & $(0.000)$ & $0.000^{* * *}$ & $(0.000)$ & $0.001^{* * *}$ & $(0.000)$ \\
\hline EDUCATION 3 & $-0^{* * *}$ & $(0.000)$ & 0.000 & $(0.000)$ & $-0.001^{* * *}$ & $(0.000)$ & 0.000 & $(0.000)$ \\
\hline EDUCATION 4 & $-0^{* * *}$ & $(0.000)$ & $-0.002^{* * *}$ & $(0.000)$ & $-0.001^{* * *}$ & $(0.000)$ & $-0.002^{* * *}$ & $(0.000)$ \\
\hline Female share & -0 & $(0.000)$ & $-0.001^{* * *}$ & $(0.000)$ & 0.000 & $(0.000)$ & $-0.001^{* * *}$ & $(0.000)$ \\
\hline Part-time share & $-0^{* * *}$ & $(0.000)$ & 0.000 & $(0.000)$ & $0.000^{* * *}$ & $(0.000)$ & 0.000 & $(0.000)$ \\
\hline Fixed-term contract sh. & $-0^{* * *}$ & $(0.000)$ & $0.001^{*}$ & $(0.000)$ & $-0.001^{* * *}$ & $(0.000)$ & $0.001^{*}$ & $(0.000)$ \\
\hline TAW share & $-0.08^{* * *}$ & $(0.008)$ & $0.037^{* *}$ & $(0.015)$ & $-0.081^{* * *}$ & $(0.008)$ & $0.036^{* *}$ & $(0.015)$ \\
\hline INDEPENDENT & -0 & $(0.007)$ & $-0.040^{* * *}$ & $(0.015)$ & -0.004 & $(0.007)$ & $-0.035^{* *}$ & $(0.015)$ \\
\hline HEADQUARTER & $-0.02^{*}$ & (0.011) & $-0.063^{* * *}$ & $(0.022)$ & $-0.020^{*}$ & (0.011) & $-0.059^{* * *}$ & $(0.022)$ \\
\hline COLLECTAGR & -0.01 & $(0.004)$ & $0.058^{* * *}$ & $(0.010)$ & $-0.008^{*}$ & (0.004) & $0.059^{* * *}$ & $(0.010)$ \\
\hline In empl. 2008 & $0.01^{*}$ & $(0.005)$ & -0.004 & $(0.014)$ & $0.010^{*}$ & $(0.005)$ & -0.005 & $(0.014)$ \\
\hline STW experience & $0.006^{* * *}$ & $(0.002)$ & & & $0.006^{* * *}$ & $(0.002)$ & $-0.008^{* * *}$ & $(0.002)$ \\
\hline WTA experience & & & $0.038^{* * *}$ & $(0.002)$ & 0.000 & $(0.001)$ & $0.039^{* * *}$ & $(0.002)$ \\
\hline Observations & 7969 & & 8053 & & 7920 & & 7920 & \\
\hline$R^{2}$ & 0.274 & & 0.215 & & 0.272 & & 0.215 & \\
\hline
\end{tabular}

Notes: Heteroscedastcity robust standard errors in parentheses. $* * *, * *, *$ denote the $1 \%-, 5 \%-$, and $10 \%$ significance levels, respectively. Dependent variables are the STW take-up rate and WTA participation rate, respectively. Each regression includes also firm size, industry and regional dummy variables. A list of the variables and their definitions is presented in Annex Table A5. 


\section{References}

Arpaia, A., Curci, N., Meyermans, E., Peschner, J. and Pierini, J. (2010), Short time working arrangements as response to cyclical fluctuations, European Commission.

Bellmann, L. and H.-D. Gerner (2010), Reversed Roles? Wage and Employment Effects of the Current Crisis, Mimeo, IAB Nuremberg.

Berkely Planning Associates and Mathematica Policy Research, Inc. (1997), Evaluation of Short-Time Compensation Programs: Final Report, Unemployment Insurance Occassional Paper No. 97-3, US Department of Labor, Employment and Training Administration, Washington, DC.

Blanchard O. J. and Tirole J. (2008), The Joint Design of Unemployment Insurance and Employment Protection: A First Pass, Journal of the European Economic Association, MIT Press, vol. 6(1), pp 45-77, 03

Boeri, T. and Garibaldi, P. (2009), "Beyond Eurosclerosis", Economic Policy, Vol. 24(59), pp. 411-461.

Burdett, K. and Wright, R. (1989), Unemployment Insurance and Short-Time Compensation: The Effects on Layoffs, Hours per Worker and Wages, Journal of Political Economy, Vol. 97, No. 6, pp. 1479-96.

Caballero, R. And Hammour, M. (1996), On the Timing and Efficiency of Creative Destruction, Quarterly Journal of Economics 446(3), pp. 805-852.

Cahuc, P. and Carcillo, St. (2011), Is short-time work a good method to keep unemployment down?, CEPR Discussion Paper 8214.

Cahuc P. and Zylberberg, A. (2008), "Reduction of working time and unemployment" in Working Hours and Job Sharing in the EU and USA, edited by Tito Boeri, Michael C. Burda and Francis Kramarz, Oxford University Press.

Calavezo, O., Duhautois, R. and Walkoviak, E. (2009), Short-time Compenation and Establishment Survival: An Empirical Analysis with French Data, Comparative Analysis of Enterprise Data (CAED) Conference, 2-4 October, Tokyo, Japan.

Crimann, A., F. Wiesner and L. Bellmann (2010), The German Work-Sharing Scheme: An Instrument for the Crisis, ILO, Conditions of Work and Employment Series No. 25, Geneva.

Crimmann, A. and F. Wiesner (2009), Verschnaufpause dank Kurzarbeit, IAB Kurzbericht 14/2009, IAB Nuremberg.

Deeke, A. (2005), Kurzarbeit als Instrument betrieblicher Flexibilität, Ergebnisse aus dem IAB Betriebspanel 2003, IAB Forschungsbericht 12/2005.

Farber, H.S., Hall, R.E. and Pencavel, J. (1993), The Incidence and Costs of Job Loss, Brookings Papers on Economic Activity, Vol. 1993, No. 1 (1993), pp. 73-132.

Feldstein, M. S,. (1976), Temporary Layoffs in the Theory of Unemployment, Journal of Political Economy, University of Chicago Press, vol. 84(5), pp. 937-57, October.

Fischer, G., F. Janik, D. Müller and A. Schmucker (2009), The IAB Establishment Panel - Things Users Should Know, European Data Watch, Schmoller's Jahrbuch, Vol. 129, pp. 133-148. 
FitzRoy, Felix R \& Hart, Robert A, 1985. "Hours, Layoffs and Unemployment Insurance Funding: Theory and Practice in an International Perspective," Economic Journal, Royal Economic Society, vol. 95(379), pp. 700-713, September

Garibaldi, P. (2006) Personnel Economics in Imperfect Labor Markets. Oxford: Oxford University Press, 2006.

Hall, R.E. and Lazear, E. (1984), The Excess Sensitivity of Layoffs and Quits to Demand, Journal of Labor Economics, Vol. 2, No. 2, pp. 233-57.

Hall, R.E. (1995) Lost Jobs, Brookings Papers on Economic Activity, Vol. 1995, No. 1 (1995), pp. 22174.

Hijzen, A. and D. Venn (2010), The Role of Short-Time Working Schemes During the 2008-2009 Recession, OECD Working Paper 115.

ILO (2010), G20 Country Brief Report - Canada, Geneva.

ILO (2010), G20 Country Brief Report - Italy, Geneva.

ILO (2010), G20 Country Brief Report - Japan, Geneva.

IMF (2010), World Economic Outlook 2010, Washington D.C.

Kölling, A. (2000), The IAB Establishment Panel, European Data Watch, Schmoller's Jahrbuch, Vol. 120 (2000), pp. 291-300.

Krugman, P. (2009), Germany's Job, Unemployment Miracle Can Teach the US, New York Times, November 17, 2009.

Möller, J. (2010), The German Labor Market Response in the World Recession - Demystifying a Miracle, Zeitschrift für Arbeitsmarktforschung, Vol. 42 (4), pp. 325-336.

Mortensen, D. T. and Pissarides, C. A. (1994), Job Creation and Job Destruction in the Theory of Unemployment, Review of Economic Studies, Blackwell Publishing, vol. 61(3), pp. 397-415, July

OECD (2010), Employment Outlook 2010, Paris.

OECD (2010), Taxing Wages 2008-2009, Paris.

Reid, F. (1985), "Reductions in work time: An assessment of employment sharing to reduce unemployment" in Work and Pay: The Canadian Labour Market, edited by W. C. Riddell, pp. 141- 169, University of Toronto Press, Toronto.

Rosen, S. (1985), Implicit Contract: A Survey, Journal of Economic Literature, 23, pp. 1144 - 1175.

Van Audenrode, M. (1994), Short-time Compensation, Job Security, and Employment Contracts: Evidence from Selected OECD Countries, Journal of Political Economy, Vol. 102, No. 1, pp. 76 102.

Visser, J. (2009), ICTWSS: Database on Institutional Characteristics of Trade Unions, Wage Setting, State Intervention and Social Pacts in 34 countries between 1960 and 2007, Amsterdam Institute for Advanced Labour Studies (AIAS), University of Amsterdam. 